NASA Technical Memorandum 83668

AIAA-84-1393

\title{
An Overview of NASA Intermittent Combustion Engine Research
}

Edward A. Willis and William T. Wintucky

Lewis Research Center

Cleveland, Ohio

Prepared for the

Twentieth Joint Propulsion Conference

cosponsored by the AIAA, SAE, and ASME

Cincinnati, Ohio, June 11-13, 1984 
$\therefore$ 


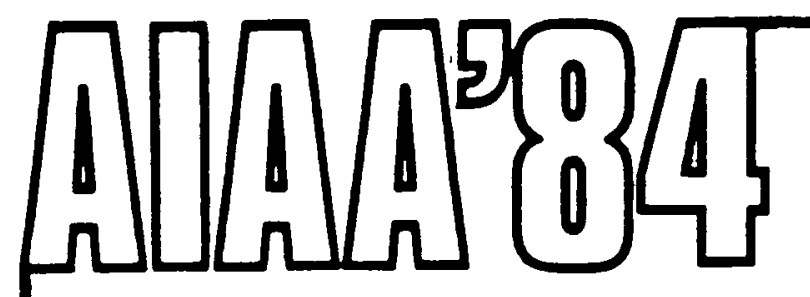

AIAA-84-1393

An Overview of NASA Intermittent

Combustion Engine Research

Edward A. Willis and William T. Wintucky

Lewis Research Center, Cleveland, $\mathrm{OH}$

\section{AIAA/SAE/ASME 20th Joint Propulsion Conference June 11-13, 1984/Cincinnati, Ohio}




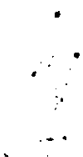




\section{Abstract}

This paper overviews the current program, whose objective is to establish the generic technology base for advanced aircraft I.C. engines of the early 1990's and beyond. The major emphas is of this paper is on developments of the past two years.

Past studies and ongoing confirmatory experimental efforts are reviewed, which show unexpectedly high potential when modern aerospace technologies are applied to inherently compact and balanced I.C. engine configurations. Currently, the program is focussed on two engine concepts -the stratified-charge, multi-fuel rotary, and the lightweight two-stroke diesel. A review is given of contracted and planned high performance onerotor and one-cylinder test engine work addressing several levels of technology. Also reviewed are basic supporting efforts, e.g., the development and experimental validation of computerized airflow and combustion process models, being performed in-house at Lewis Research Center and by university grants.

\section{Introduction}

This paper summarizes NASA's ongoing efforts in aircraft intermittent combustion (I.C.) engine Research and Technology ( $R$ and $T$ ), with emphasis on recent developments which are not addressed in concurrent publications. As Fig. 1 indicates, this is a research-oriented program whose objective is to establish the generic technology base for advanced aircraft I.C. engines of the early 1990's and beyond, To review briefly, past engine studies, $1^{-3}$ now partially confirmed by experimental results, ${ }^{4-8}$ have shown unexpectedly high potential when modern aerospace technologies were applied to inherently compact and balanced I.C. engine configurations such as the Wankel rotary. Figure 2 illustrates three advanced I.C. engine concepts that were studied, and displays their attractive estimated cruise BSFC's and specific weights. In addition, parallel studies ${ }^{9}$ of small, highly advanced, simple-cycle turbine engines were also conducted, and also yielded encouraging results. Figure 3 illustrates a typical comparison based on these prior studies. In the sub-500 hp category, typjgal, fixed- and rotarywing mission comparisons $10-12$ showed fuel burn savings of about 50 percent and airplane size reductions approximating 25 percent, compared to a traditional reciprocating engine. The same studies showed advanced I.C. engine fuel savings approaching 35 percent relative to a small, highly advanced, simple-cycle turbine. Subsequent I.C. engine studies $13-14$ in the 800 to $2400 \mathrm{hp}$ range indicated attractive results in this category as well. Although encouraging preliminary jpdications for helicopters have been derived, 15 based on results of the Army's ongoing Adiabatic Diesel
$R$ and $D$ efforts, 16 comprehensive mission evaluation studies of larger advanced I.C. engines have not yet been performed. This paper includes the results of a limited range of studies conducted by the Army's Research and Technology Laboratories for a light-weight helicopter.

Currently, the research program is focussed on two engine concepts -- the stratified-charge, multi-fuel rotary and the lightweight two-stroke dieser. High performance one-rotor and onecylinder test engines and related engine-specific items are being developed under ongoing contracts with Curtiss-Wright/Deere and Co. and Teledyne Continental Motors/General Products Division, respectively. These two ongoing test-engine contracts, both approaching completion, are briefly reviewed. Beginning in mid-1985, comparative data from the final test engine builds will be used to further assess the technical merits of the two concepts. By late 1985, one or the other could be identified as the prime candidate for a potential, larger follow-on program involving additional technology work and a turbocharged, multi-rotor or multi-cylinder breadboard engine. Related supporting efforts of a more basic nature are also summarized; e.g., the development and experimental validation of computerized airflow and combustion process models, seal and adiabatic material/ component research. These are being performed in-house at Lewis Research Center and by university grants.

Finally, the planning to date for a separate but closely related Army/NASA joint program in the compound diesel-turbine area is discussed. Funded by various DOD sources, this project addresses $h$ igher power ratings and more aggressive technology than would be appropriate for general aviation. This project, called ADEPT for Advanced Diesel Engine Propulsion Technology, will build upon the technical base established by Garrett TEC in a previous, DARPA-funded program. 17 The recentlyinitiated first phase encompasses single-cylinder research at unprecedented speeds and operating pressures, together with design and application studies of a three-cylinder test rig and multicylinder engines in the 500-1500 hp range.

A bibliography of recent reports/papers on the foregoing is included.

\section{Fuel Impact}

As is well known, the cost of fuel has become a major part of the cost of doing business for most segments of aviation. Although the present "oil glut" has relieved these pressures temporarily, long-range predictions 18 indicate that the trends of the past decade will continue indefinitely. This situation, as it affects light aviation, was considered during the "Workshop on Axiation Gasolines and Future Alternatives, "19 held at 
Lewis Research Center in February 1981. After considering such factors as supply, potential demand, refinery capabilities, and distribution, it was concluded that commodity-type jet fuel will remain in relatively good supply and generally available for at least the next 30 years. Aviation gasoline (avgas), on the other hand, was perceived as being of doubtful availability over the same span of time. It was further concluded that jet fuel should be used as the fuel of choice for any all-new light aviation powerplant of the future.

This conclusion has major ramifications for powerplant design, especialiy in the lowerhorsepower area where the predominant engine today is the air-cooled reciprocating engine, which requires high octane avgas. Jet fuels in general have low octane numbers and, moreover, their properties of interest for I.C. engines (octane and/or cetane numbers) are not controlled by specifications and probably never will be. Thus, even though domestic, kerosine-type "Jet-A" fuel presently has a good cetane rating and is an excellent diesel fuel, there is no assurance that this will continue to be the case in future times or other localities. On the contrary, commercial jet fuel specifications are expected to evolve in a "broadspec" direction, more similar to present military jet fuels (which have neither good octane nor good cetane ratings).

To be competitive in this scenario, the new I.C. powerplant clearly needs a type of combustion system which will be insensitive to cetane and octane ratings. One such system, known as "stratified-charge," employs diesel-type direct fuel-injection over a spark plug, to assure immediate ignition. This establishes a localized flame front which is then sustained by continued injection of fuel, with air flow supplied by the engine's internal aerodynamics.

\section{Rotary Engine $R$ and $T$}

Although many types of I.C. engines can employ the stratified-charge combustion concept in one form or another, it has proven to be particularly suited to the rotary due to the inherent air motion and geometry of the iatter. Previous experience at curtiss-Wright 7,8 has demonstrated at low BMEP that this enables the rotary to burn a variety of different fuels, while at the same time raising its historically lower efficiency to a level approaching automotive diesels. Most recently, the former Curtiss-Wright rotary engine business was purchased by Deere and Co., with a view towards selected commercial and military applications. These developments, combined with its inherent, and already known technical characteristics (compactness, light weight, low vibration, etc.) make the rotary a natural candidate for light aircraft.

As indicated in Fig. 4, the current rotary $R$ and $T$ program encompasses in-house and contract activities in four main areas of technology. These include not only stratified-charge combustion as previously discussed, but also tribological, structural, and turbomachinery work to realize this form of combustion in a practical, competitive engine.
Stratified-charge combustion meets the need for fuel flexibility in rotary engines. As Fig. 5 suggests, the basic problem is to get the fuel and air together and burn them rapidly enough to maintain good efficiency. As indicated, the process of doing this entails significant efforts in several major areas, including internal aerodynamics, fuel-injection, and ignition. (Areas in which efforts are already ongoing are shown in the shaded areas of the chart; planned future efforts are listed in the unshaded region. This convention will be followed in later charts as well.) Initially, it also required significant effort to develop the specialized diagnostic instrumentation required to investigate these processes in a firing engine environment. For example, the IMEP of a rotary engine is difficult to measure in-situ, because there is no single point on the stationary housing from which a pressure transducer can "see" the entire thermodynamic cycle. A recent solution to this problem consisted of electronically combining the signals from four strategically located pressure pick-ups to reconstruct the complete pressure-time history. 20 Combined with prevjously developed microprocessor circuitry, 21,22 this now enables the IMEP and other combustion parameters of a rotary engine to be observed on a real-time, cycle-by-cycle basis.

Given the ability to measure the overall behavior of the combustion chamber, the next requirement is to develop a sufficiently good understanding of detailed processes inside, so that directions of improvement can be rationally predicted. In general, the approach taken has been to develop computer models of the airflow and other processes, then use LDV and related techniques to verify/refine the codes' predictions. Modeling efforts are now underway at Massachusetts Institute of Technology and the University of Florida. First-cut versions of these recentlyinitiated efforts are now operational, and they will be further discussed in a parallel presentation.

Meanwhile, the rotary's inherent shape, motion and airflow patterns lend themselves naturally to stratified-charge operation. In Fig. 6, air flow relative to the rotor, approximately determined by an early in-house flow model, is plotted at various stations approaching Top Dead Center (TDC). As may be seen, this relative flow combined with the rotor's own motion results in a strong, unidirectional air motion in the downstream direction. In this simple model, it appears sufficient to merely spray in fuel, at a rate proportional to the instantaneous airflow across the injector station, to maintain a standing flame front. In some cases, positive ignition is assured by dividing the fuel flow. The smaller or "pilot" flow is finely atomized and directed over a spark plug to create an energetic "blow-torch" effect. This in turn vaporizes and ignites the incoming main charge with minimal delay.

In order to study these processes experimentally, an existing engine test rig of this general type has been procured from Outboard Marine Corporation $(O M C)$, and a high-output second rig, embodying features identified in the earlier studies, is being designed and built for NASA by Curtiss-Wright and Deere and Company. The OMC rig 
is illustrated in Fig. 7. It is currently undergoing calibration and initial shakedown operations, and should reach a productive, data-gathering status later in the year. Meanwhile, the similarsized $\left(40\right.$ in $^{3}$ ) but higher performing Curtiss-Wright/Deere rig appears to be proceeding on schedule. Barring unforseen problems, assembly of the first article should begin in the final quarter of FY84, with acceptance test and delivery by early FY85.

\section{Seals and Lubrication}

Seal and lubrication problems for rotary engines are both different and difficult compared to conventional (reciprocating) I.C. engines. Most notably different is the apex seal, because of its line-contact nature and unidirectional motion. Despite this, seal and other mechanical problems appear to be minimal in late-model rotary automobile engines. The advanced rotary aircraft study however, called for sliding speeds and operating pressures which are $1-1 / 2$ and 2 times, respective$1 y$, the maximum values seen in automotive practice. These factors, together with the prolonged highoutput running typical of the aircraft duty cycle, result in high contact pressures and operating temperatures - both of the seals and their mating surfaces. For these reasons, the friction and wear characteristics of apex seals and their associated lubricants are again matters of concern. In addition, recent research ${ }^{23}$ suggests, on theoretical grounds, that the rotor side seals may contribute an unexpectedly high proportion of the engine's total friction.

As indicated in Fig. 8, a number of seal/ trochoid surface material combinations have been or are being tried. Among the proven combinations, the original Mazda one-piece (graphite against cracked-chrome) design, gives low friction, adequate sealing at high speeds and is still frequently used for racing applications. Unfortunately, the graphite is so brittle that it cannot be fabricated into a two-piece seal. Its low speed sealing effectiveness is therefore marginal, and its long-term durability is suspect. The more recent two-piece iron/chrome combination gives much improved low speed sealing, and apparently wears well in automotive service. The ceramic seals are of great interest for reduced friction and their potential ability to stand up to a very high temperature environment, as may exist in an "adiabatic" or "minimum heat rejection (MHR)" version of the engine. (The terms "adiabatic" and "MHR" are used synonymously and interchangeably in this paper.)

New seal/trochoid material combinations are normally screened on a friction and wear rig apparatus such as the pin-and-disc tester illustrated schematically in Fig. 9. Several graphite fiberpolyimide composite materials were evaluated in an effort to find a better trade-off between friction and low speed sealing. Although numergus specimens were tested to obtain basic data, 24 the emphasis has now shifted to ceramics and other high-temperature materials. At present, specimens of several ceramic seal candidate materials are ready for pin-and-disc screening, and a sample set of partially-stabilized zirconia (PSZ) apex seals has been fabricated to demonstrate surface finish, dimensional characteristics and physical properties. The PSZ seals are compared with conventional iron and graphite seals in Fig. 10.

When screening tests are complete, selected specimen seals will be further evaluated in a hotfiring engine environment. Figure 11 shows a simple, but high-output, single-rotor, 35 cubic inch test rig engine that has been assembled for this purpose out of Mazda competition components. This gasoline-fueled rig has been acceptance tested at $125 \mathrm{hp}$ at $9,500 \mathrm{rpm}$ for brjef intervals. Its specific output $\left(3.7 \mathrm{hp} / \mathrm{in}^{3}\right)$ could be raised by turbocharging, but is already close to that of the Curtiss-wright/Deere rig $\left(4.0 \mathrm{hp} / \mathrm{in}^{3}\right)$. This will permit meaningful seal and lubricant testing to begin expeditiously, without impacting the stratified-charge $R$ and $D$ efforts.

Thermal Technology

In recent years, much has been said about the benefits of operating a diesel engine in the "adiabatic", turbo-compound mode. (Recall that, for our present purposes, this terminology includes MHR engines as well as those having essentially zero coolant heat rejection.) This means that most or all of the combustion space (piston crown, fire deck and cylinder wall) is lined with ceramic or other high temperature insulating materials. As a result, heat losses to the coolant are greatly reduced or eliminated. The energy saved primarily shows up as increased exhaust-gas energy -hence a compounding turbine is needed to recover a portion of it. With this technique, BSFC's as low as 0.285 lbs/bhp-hr have been reported 16 for a truck-type diesel engine.

Although no prior research has been reported along these lines for rotaries, there is no apparent technical reason why it could not be done. Relative benefits in fact may be greater, since the conventional rotary experiences a relatively larger coolant heat rejection already (compared to a similar piston engine), and combustion tends to be slow in its elongated, well-quenched combustion space. Both factors degrade indicated efficiency, and in current rotaries, the deficit is only partly made up by lower friction. But by minimizing coolant heat losses (a larger percent of the total than in piston engines), and in achieving faster combustion (by replacing cool quench areas with hot reaction - promoting areas), the "adiabatic" or MHR rotary may for the first time achieve better efficiency than a comparable piston engine.

Several approaches are planned or currently under study, as shown in Fig. 12. In general, these comprise the use of ceramic, composite or high-temperature metallic materials for rotor and housing wall surfaces. Each component presents its own unique problems and must be carefully analyzed to identify the necessary trade-offs between thermal, stress, and sealing-surface considerations. Figure 13 indicates, in a very approximate and over-simplified manner, the change in peak-load heat flux across the hottest part of the trochoid wall, if the present $3 / 16$ in. aluminum were to be replaced by $3 / 16$ in. of a material having a thermal conductivity approximating PSZ. The effect on the initially very high heat flux is dramatic -- a factor of 2.5 reduction is clearly indicated. Applying this factor to the 35 percent coolant heat rejection typical of small rotary 
engines, indicates that considerably more energy (21 percent of fuel input) will now be presented to the compounding turbine. Depending on pressure ratios (before and after converting to adiabatic operation), and the component efficiencies involved, it could be argued that on the order of 10 percent more power could be extracted from an already turbo-compounded engine. All that is needed is a high-temperature insulative wall, plus high temperature seals to run against it. This is no small task, however. It is an essentially new area of research for rotary engines per se analytical investigations were initiated in late 1983 and are being extended now to include finiteelement calculations. The incentive however, is clearly very large.

\section{Turbocharging and Compounding}

Figure 14 indicates the main program elements related to turbocharging. All I.C. engines in the previously mentioned studies were highly turbocharged, to obtain high power densities and the benefits of flat rating up to 25000 feet altitude. Various assumptions were made by the engine manufacturers concerning the appropriate turbocharger cycle parameters and component efficiencies. More recently, a study 25 of a general aviation oriented turbocharger technology needs and benefits was conducted for NASA by Garrett Turbine Engine Company (GTEC). As the rotary engine's turbocharger requirements (flow, pressure ratio, etc.) were generally midway between the other two study engines, it was chosen as the representative advanced I.C. engine for the purposes of the GTEC efforts. Results from then-current NASA turbocharged rotary engine research ${ }^{26}$ and

Curtiss-Wright IR and $D$ programs were fed into the GTEC study at an early point to help define the applicable vibratory environment, exhaust gas conditions, engine flow characteristics, and pulseenergy recovery characteristics. Based on this type of input, plus the original engine study data, GTEC concluded that very attractive levels of performance, weight, and package size were possible, given appropriate advances in four key technologies: (1) a ceramic turbine rotor; contained in (2) a lightweight, sheet metal turbine housing; (3) a full air-bearing suspension system; and (4) modest improvements in compressor aerodynamics.

Figure 15 compares the resulting advanced turbocharger with current practice. Part (a) i1lustrates the present GTEC concept, which outperforms a single conventional unit with similar external dimensions, yet weighs half as much. To obtain comparable performance with current technology, a two-stage series system with an interstage cooler is required. This is illustrated in part (b) at roughly the same scale. The advanced technology design is not only much lighter, but considerably smaller - the conventional system is nearly as large as the rotary engine itself. Since a full air bearing suspension is used, there is no oil internal to the advanced turbocharger. It would therefore present no fire hazard in the event of a failure.

A compounding turbine was included in one of the prior, general aviation-related engine studies. 1 In that case, the substantial heat losses to the (conventional) cooling system and the energy extracted to drive the high altitude turbocharger left little to be recovered by com- pounding. A degree of synergism emerges, however, when compounding is used together with the "adiabatic" or MHR type of engine structure. That is, a large benefit results from the combination of two technologies which would individually produce only marginal gains. Although the first-order needs of general aviation can (arguably) be met without the use of these technologies, they are clearly indicated for higher power applications where the competition is more effective and higher costs may be allowable.

Turbocharging and compounding technology, however, is not being actively pursued by NASA at present. This is not to minimize the importance of having the right turbocharger at the right time, or of having an appropriate compounding turbine at some later time. The power core, be it rotary or diesel, is simpiy viewed as being the larger, more critical and riskier task, and one that is much less likely to benefit from ongoing, well-funded programs in the small-turbine area.

\section{Diese 1 Engine $\mathrm{R}$ and $\mathrm{T}$}

The very concept of using a diesel engine in an airplane always seems to be taken skeptically, yet the idea is by no means new. The diesel aircraft engine actually predates the jet engine in flight by about two decades, and a textbook on the subject 27 had been published by 1940 . Experimental diesels were built and flown in the U.S. and several European countries during the 1920 's and 1930's. In Germany, the "Jumo" series of aircraft diesels reached production status in the early 1930's, and then remained in continuous production and service, for transport and long-range patrol airplanes, for about a decade thereafter. In the half-century since the first Jumo diesel entered service, few if any other production, shaft-power aircraft engines have equalled its cruise BSFC of $0.36 \mathrm{lbs} / \mathrm{bhp}-\mathrm{hr}$.

In today's more energy-conscious world, it seemed only logical to re-examine this concept in the light of modern technologies. Therefore, the diesel was included in the previous light-aircraft powerplant studies, with favorable results as described previously. The next problem was to establish the technical credibility of the study results. The approach chosen by NASA includes contracted, engine-specific $R$ and D work using a single cylinder test engine (SCTE), supplemented by Lewis Research Center's in-house basic research support in the internal-airflow modelling area. Figure 16 indicates the main objectives of this work. As may be seen, these are closely parallel to the rotary objectives previously discussed. That is, technologies related to (1) combustion/ fuel-injection; (2) piston ring and cylinder sealing, friction, wear and lubrication; (3) application of high temperature, insulative materials to combustion-chamber components; and (4) airflow and turbocharging considerations, will all require significant attention. Since both the contracted portion of the NASA diesel activities and the supporting in-house airflow modeling work are the subjects of parallel presentations, they will be only briefly summarized here for the sake of continuity. 


\section{Contract Activity}

The ongoing SCTE research contract (fig. 17) with Teledyne Continental Motors/General Products Division (GPD) focusses on a cylinder, piston, and combustion chamber design established in the original study. 2 Initiated in FY81 at a low level of effort, the program addresses those technologies that are believed to be necessary for future light aviation powerplants of $400 \mathrm{hp}$ and below. Figure 18 illustrates the SCTE, consisting of the NASA cylinder, piston, and combustion chamber assembled onto a standard, laboratory type test crankcase. Inlet air and exhaust ducting for this loop-scavenged, piston-ported design are clearly visible. Figure 19 presents results from tests to date of several engine builds. Shown are several engine operating parameters and specific fuel consumption over a range of indicated mean effective pressure (IMEP). An early build of the engine is represented by triangle symbols while a recent build, with a significantly better fuel-injection pump, is shown by circles. Vertical lines at IMEP's of 9.2 and 12.4 bars represent four-cylinder cruise power (250 bhp) and take-off power ( 360 bhp) at the $3500 \mathrm{rpm}$ condition tested. Looking first at the peak cylinder pressures at the top of the chart -- it may be seen most clearly that the early build could not meet either of the specified power levels and also exceeded the design pressure limit of about 100 bars (1500 psi). The later build, by contrast, easily met these criteria, and in fact indicated that the engine could exceed its original take-off hp rating. Its brake and indicated SFC's (bottom data) bracket the value of about $220 \mathrm{~g} / \mathrm{kw}-\mathrm{hr}$ (approximately $0.36 \mathrm{lbs} / \mathrm{bhp}-\mathrm{hr}$ ) predicted for the study engine. As a four-cylinder engine normally has lower specific friction losses than a SCTE, this indicates that the predicted performance levels can probably be met from an engine point of view.

The preceding results were obtained using shop-air pressurization on an "as-required" basis, in place of an actual turbocharger. Cycle-match studies were also conducted to compare measured SCTE inlet and exhaust conditions with projected turbocharger maps. These calculations now indicate that the present configuration of the engine does not provide enough exhaust energy to drive a realistic definition of the advanced turbocharger, to obtain the needed inlet air flow and pressure ratio. One way to obtain the needed energy is to insulate the interior surfaces exposed to combustion, using ceramics or other high temperature materials. Unfortunately, this converts the use of "adiabatic" or MHR-type engine structural components from an optional later improvement into a primary requirement for an aircraft diesel. Such components have been experimentally run, with apparent success for truck engines, in the Army (TACOM) Adiabatic Diesel program. ${ }^{16}$ At present, a finite-element computational program is ongoing to evaluate various materials for their temperature, stress and heat-flux characteristics in engine components. Figure 20 illustrates a typical computational grid for a cylinder liner.

\section{Airflow Modeling}

Because of the previously mentioned critical nature of the "match" between a two-stroke I.C. engine and its turbocharger, a detailed under- standing of the airflow through and inside of the two-stroke cylinder is essential. This is presently being addressed by a long-range basic effort including significant in-house and unixersjty grant solving the two-dimensional axisymmetric Navier-Stokes equations are well along in development and have already been applied to generate simulated motion pictures of the airflow inside selected configurations. Figure 21 is based on a single frame from such a movie. Illustrated is an axisymmetric intake flow through a single, centrally-located valve, resulting in the formation of two vortical structures as shown. Clearly, the persistence of such vortices into the fuelinjection and combustion events would have a sjgnificant effect on the latter. A recent study 29 using the present methods defined the conditions under which these vortices may persist long enough to affect combustion.

Most recently, the emphasjs has been on using laser-optic and holographic 31 imagery to verify the computer-predicted flow patterns such as those illustrated in Fig. 21.

Advanced Diesel Engine Propulsion Technology

(ADEPT) Project

The "Advanced Diesel Engine Propulsion Technology" (ADEPT) project is a joint Army/NASA program to demonstrate the technology for an exceptionally high performance diesel power core. This in turn is viewed as a first step toward a "Compound Cycle Turbine Diesel Engine" (CCTDE) propulsion system. The CCTDE, as illustrated in Fig. 22, is a highly turbocharged, power compounded, very advanced diesel engine of much higher specific power (up to $5 \mathrm{hp} / \mathrm{in}^{3}$ ) than presently being considered for any known future civil or military application. The Army Aviation Systems Command (AVSCOM), in particular, is interested in the CCTDE concept as a potential candidate for future advanced helicopter applications. Other DOD organizations are also interested in CCTDE for combat vehicles and 1 anding craft. A preliminary study 15 showed that use of a high specific-power compound diesel engine could save up to 40 percent in helicopter fuel requirements. Recent unpublished analyses by the AVSCOM (discussed in the next section) indicated that in addition to the 40 percent savings in fuel, up to a 25 percent reduction in engine power requirement could be possible compared to an equivalent advanced simple cycle gas turbine engine. This reduction in power required also translated into a smaller helicopter for the same payload and mission. Based on these potential advantages, the IJ.S. Army Aviation Systems Command (AVSCOM) has entered into an agreement with NASA for a joint program on the "ADEPT" technology effort precursory to CCTDE.

The basis for the ADEPT/CCTDE effort is a previous Compound Cycle Turbofan engine (CCTE) project conducted by Garrett Turbine Engine Company under a DARPA/Air Force program 17 from 1977 through 1981 (fig. 23). In this advanced turbine engine concept, the conventional combustor of a turbofan was replaced with a highly turbocharged, high-speed, direct fuel-injected, twostroke cycle diesel power core. This diesel power core along with a directly geared exhaust gas turbine drove the turbine engine compressor and pro- 
pulsive fan. Design life of the engine was 25 hours and speed/load range changes were 1 imited with minimal operation at peak power. During the CCTE program, performance goals of $8000 \mathrm{rpm}, 4000$ $\mathrm{ft} / \mathrm{min}$ piston speed, $7.2 \mathrm{hp} / \mathrm{in}^{3}$ power density and 385 psi brake mean effective pressure were demonstrated on single-cylinder engines. Development of diesel power core critical technologies was addressed in the following areas: cylinder breathing/scavenging, fuel injection, combustion and materials/lubricants.

The compound cycle diesel/turbine engine has many potential benefits as illustrated in Fig. 24. It is now being considered by the Army for future high-performance helicopters because of advantages such as: very low fuel consumption; the potential increase in range times payload product; and/or reduced size and weight of an aircraft to perform a given mission. Reduced mission fuel requirement is further translated into a major logistics reduction of fuel, manpower, and equipment required to support the entire aircraft fleet. The diesel engine has the lowest demonstrated specific fuel consumption ( $\leq 0.30 \mathrm{lb} / \mathrm{hp}-\mathrm{hr})$ of any practical engine. Long life and reliability of the diesel have been demonstrated in other applications. Specific power of $4.8 \mathrm{hp} / \mathrm{in}^{3}$ and 6000 rpm for this engine was demonstrated in the previous compound cycle turbine engine program. These high specific power and speeds in a two-stroke cycle engine lead to a substantial reduction in specific weight $(0.5$ to $0.7 \mathrm{lb} / \mathrm{hp}$ depending on power level and application), and size over the more conventional operational diesel. The estimated potential size and volume of the compound diesel is as about the same as a current simplecycle gas turbine for the same application. other attributes of this diesel concept are: low exhaust gas temperatures of $550^{\circ}$ to $750^{\circ} \mathrm{F}$ depending on power level, low cruise SCF well into partpower range, and low idle fuel consumption compared to the gas turbine. The response rate of the engine can be rapid since it can be run at constant speed with power level changed by changing fuel flow rate. Substantial emergency power boost $c$ an be achieved by a variety or combination of methods such as over-fueling, pressure boosting, and water/methanol injection.

For the compound turbine diesel engine CCTDE program, the target for design life is 2000 operational hours. To meet the extended life target, the previous (CCTE) program's engine power, density, and speed targets have been reduced to 4.8 $\mathrm{hp} / \mathrm{in}^{3}$ of engine displacement and $6000 \mathrm{rpm}$ respectively, and need to be traded off and optimized for CCTDE. CCTDE's potential life and reliability also need to be assessed to establish its credibility and technology base. A three year ADEPT program for generic technology development to validate feasibility, performance, and technology has been established as the first portion of a two part program, as shown in Fig. 25. Initially, component $R$ and $D$ will be pursued as an extension of CCTE's generic critical technologies (high speed and pressure injection, piston ring lubrication and wear, inter-cylinder gas dynamics, and high temperature-stressed materials) to demonstrate performance levels and reliability. A number of parametric system studies will be performed for military applications, such as helicopters, combat vehicles and landing craft. The first study and experimental efforts will focus on helicopter ap- plications. After the system studies have been completed and critical technologies demonstrated, a design will be performed of a multi-cylinder engine test rig. The purpose of this test rig is to combine individual technologies to evaluate their characteristics, relationships, and effects on an overall system performance. The CCTDE portion (a five year effort) of the overall program would start with the fabrication and testing of the three-cylinder engine test rig designed under ADEPT. Component development would continue in order to complete demonstration of life and reliability. The program would culiminate in a fully compounded, experimental complete CCTDE engine demonstration.

\section{Rotorcraft Applications}

As previously mentioned, earlier studies by NASA and AVRADCOM (now AVSCOM), indicated that there was a large potential reduction in helicopter fuel consumption for a given mission with the use of advanced I.C. engines compared to advanced turbine engines. A mission analysis study by NASA IO of two civilian helicopter sizes and missions indicated the following: (1) a single engine, fourplace helicopter with a 800 ib payload capacity and $300 \mathrm{n} \mathrm{mi}$ range powered by a very advanced I.C. engine would use 40 percent less fuel than a vehicle powered by an advanced simple-cycle gas turbine; and (2) a twin engine, six-place advanced I.C. engine powered helicopter with a $1200 \mathrm{lb}$ payload and $500 \mathrm{n} \mathrm{mi} \mathrm{range} \mathrm{would} \mathrm{use} 30$ percent less fuel than one powered by an advanced sjmple-cycle gas turbine. The early AVRADCOM study 15 compared rotorcraft performance with hypothetical adiabatic diesel engines (BSFC of $0,285 \mathrm{lb} / \mathrm{hp}-\mathrm{hr}$, based on the TACOM/Cummins results 16 ) with that representative of the Army's Advanced Technology (turboshaft) Engines in a typical mission. This showed a nearly 40 percent savings in mission fuel with compound diesel engines. The early study treated the diesel engine's specific weight as a parametric variable, and showed that a break-even value of $0.76 \mathrm{lb} / \mathrm{hp}$ would result in the same vehicle gross weight as the much lighter turbine, due to the savings in transmission, fuel, tankage, and related weights. These are encouraging indications that advanced I.C. engines could compete effectively with turbine engines for powering rotorcraft.

Based on the foregoing, plus the very attractive weight, envelope, and performance estimates from the CCTE program, the Army is seriously considering a highly-turbocharged, compounded turbine diesel engine (CCTDE), as a contender with turbine engines. Preliminary estimates are that it would have a BSFC of $0.30 \mathrm{lb} / \mathrm{hp}-\mathrm{hr}$ and weigh about 0.62 lb/hp for light helicopter applications. In order to make a direct size comparison with a known advanced technology turbine engine, a $1500 \mathrm{hp} \mathrm{CCTDE}$ was estimated by scaling, and the results are compared to the T700 turbine engine in Fig. 26. The two engines are about the same size with CCTDE being about two inches shorter, but about two inches larger in diameter than the T700 engine. In this size range, specific weight is estimated to fall between $0.50 \mathrm{lb} / \mathrm{hp}$ (750 lbs) and $0.62 \mathrm{lb} / \mathrm{hp}$ (930 lbs).

In a study of advanced rotary combustion engines for commuter aircraft, ${ }^{14}$ a turbo-compounded engine concept was developed which had an entirely 
different shape factor (fig. 27). This rotary engine concept has minimal frontal area, but a greater length. For a $1500 \mathrm{hp}$ version, the rotary engine compared to the T700 gas turbine would be about two inches smaller in diameter, but almost twice as long. It lends itself to a very streamlined, low-drag nacelle shape. An "adiabatic" (minimum heat rejection or MHR) version of the turbo-compounded rotary engine is estimated to weigh 931 lbs and have a BSFC of $0.30 \mathrm{lb} / \mathrm{hp}-\mathrm{hr}$ which approaches the CCTDE.

An artist's concept of a typical tilt-rotor version of a mid-sized rotorcraft is shown in Fig. 28. Both CCTDE and the adiabatic rotary I.C. engines could fit the rotorcraft nacelles, and can be powerplant candidates for similar future applications.

A recent (unpublished) analysis by AVSCOM compares the performance of CCTDE with representative simple-cycle advanced turbine engines for tilt rotor, pure helicopter, and compound helicopter vehicles. Figure 28 illustrates the general arrangement of the tilt-rotor version. The analysis was conducted for a typical Army two hour mission for vehicles in the 8000 ib to $120001 \mathrm{~b}$ class with equal payloads and a one-half hour fuel reserve. The entire mission was assumed to be flown at 4000 feet and $95^{\circ} \mathrm{F}$. Minimum performance vehicle required was $200 \mathrm{kn}$ forward speed and 500 $\mathrm{ft} / \mathrm{s}$ vertical climb rate. The rotorcraft fuselage was "rubberized" to allow for variable tankage, fuel and power, and drive system sizes to accommodate two turbine or two CCTDE engines in each of the rotorcraft vehicle types. Mission equipment was held constant. Consistent with the design point of 4000 feet and $95^{\circ} \mathrm{F}$, sea level/standard day (SL/STD) specific fuel consumption and weight of the simple-cycle turbine were $0.45 \mathrm{lb} / \mathrm{hp}-\mathrm{hr}$ and $0.23 \mathrm{lb} / \mathrm{hp}$. For the CCTDE, $0.30 \mathrm{lb} / \mathrm{hp}-\mathrm{hr}$ and 0.62 $\mathrm{Ib} / \mathrm{hp}$ were used. Results of the analysis presented in Fig. 29 show that for three types of rotorcraft (tilt rotor, pure helicopter and compound helicopter), the quantity of fuel required with CCTDE engines ranged from 37 to 42 percent less than with turbine engines. Installed power required with the CCTDE in performing the same mission for the three rotorcraft types was 24 to 30 percent less than that required with turbine engines. It should be noted that, because of the 4000 feet, $95^{\circ} \mathrm{F}$ design requirements, and inherent lapse rate power characteristics, the turbine engine SL/STD IRP required was about 50 percent greater than design at 4000 feet altitude. The required oversizing of the turbine engine contributed to the greater size and weight of the resulting rotorcraft. The CCTDE engine has no lapse rate penalty until a critical altitude (higher than normal rotorcraft operation) is reached, determined as a function of its turbocharger characteristics.

In order to make a comparison of CCTDE with a more advanced gas turbine, an analys is of a pure rotorcraft including a regenerative gas turbine was performed for the previous mission. Table I shows the analysis results and comparison with the simple-cycle turbine ATE, the regenerated turbine, and CCTDE. Note that results are normalized to the ATE's power level (IRP) and associated weights. The regenerative gas turbine rotorcraft had about the same installed power as with the simple-cycle turbine engine. Although the regenerative gas turbine SL/STD design point BSFC was $0.35 \mathrm{lb} / \mathrm{hp}-\mathrm{hr}$, reduced fuel consumption only made up the difference between fuel weight burned and the increased engine weight. The net result of use of the regenerative turbine engine was only a lower fuel requirement than the simple turbine engine with both turbine-type rotorcraft having about the same installed power and gross weight. The CCTDE powered rotorcraft still retains a significant edge in less fuel burned, less power required and lower vehicle weight (both empty and gross). If the mission gross weight for the CCTDE powered rotorcraft was kept the same as that of the gas turbine, the resultant additional possible fuel load could increase mission time by up to 50 percent, and range by up to 80 percent. Alternatively, the fuel-related weight saved for equal range and gross weight could be applied to increased payload ( +45 percent), thus arguably increasing the combat effectiveness of this vehicle by a major factor.

Although the rotary engine was not included in the analysis, the "adiabatic" or minimum heat rejection (MHR) rotary should also be competitive since its projected weight and performance characteristics are close to the CCTDE. It also appears that a less ambitious, general aviation technology level rotary engine ${ }^{14}$ of the proper size could approach a standoff in rotorcraft performance compared to either of the two gas turbines considered.

Diesel and stratified-charge rotary I.C. engines can easily use jet fuel and present some very desirable operational characteristics for rotorcraft compared to gas turbines. These include zero lapse rate, low fuel consumption, and increased range times payload product, as already mentioned. During all maneuvers, engine (i.e., rotor) speed can be maintained almost constant with power being controlled only by the rate of fuel injection and, to some extent, by engine compression drag. Therefore, engine power response rate would be rapid. With the advancing technology of I.C. engines, their use in future rotorcraft can result in substantially improved performance compared to that with gas turbine power.

\section{Discussion}

The concept of using an advanced, truty modern I.C. engine as a light aircraft powerplant was identified by NASA Lewis Research Center in the mid 1970 's. Although aircraft I.C. engine research was largely abandoned after World War II, subsequent advances in materials, tribology and other generic areas are nevertheless applicable and beneficial in many cases. It was recognized that the combination of modern aerospace technologies with an inherently compact, balanced engine concept and up-to-date design and manufacturing techniques could provide a remarkably fuel-efficient aircraft powerplant. In order to be successful, however, aircraft speed, altitude capability, and cabin comfort (noise and vibration) would have to be competitive with a turboprop airplane, while the cost of the new engine $(\$ / \mathrm{hp})$ should not greatly exceed the cost of today's gasoline reciprocating engines. These objectives established the basis for the technology approach in this emerging program.

A substantial number of studies related to this concept have been conducted by NASA and major engine and airframe manufacturers to further clarify its potential. These studies have all shown 
fuel savings of 25 to 50 percent are possible, depending on the particular application and baseline chosen. This appears to be the largest single technology gain for light aircraft that has been identified in the post-war era. Based on the longterm average Free World aviation gasoline fuel consumption, (roughly one-half billion gallons/ year), a one-half billion to one billion gallon fuel savings should be recorded by the end of a ten-year, new-technology introduction period.

A long-term, phased $R$ and $T$ approach was adopted by NASA for the advanced I.C. engine work. This approach was chosen because of the originally unknown, high technological risks in obtaining the required levels of efficiency, power density, structural integrity, low vibration and noise, and clean low-drag aerodynamic installation, all in the same low-cost package. In the initial $R$ and $T$ phase (1977 to present), several fully modern I.C. engine test cells were activated at NASA's Lewis Research Center. Sophisticated instrumentation, diagnostic techniques and computer-based analysis programs were developed as appropriate, most of which are at or near the forefront of I.C. engine research worldwide. Numerous low-cost engine test rigs of both the rotary (Wankel) and piston varieties have been built and tested with these newly available capabilities. Ongoing research emphasis includes efforts on basic combustion and internal airflow phenomena for multi-fuel capability, as shown in Fig. 30, plus work on seals and lubrication, and high temperature insulative materials. In addition to the Lewis Research Center in-house efforts, related contract/grant activities were and are being sponsored with appropriate elements of the industry and university communities.

Since 1977 the Lewis Research Center's efforts have averaged around 20 research and support manyears per year with a contracting budget of $\$ 0.5$ million to $\$ 1.5$ million annually. In addition to NASA's efforts, various DOD agencies have sponsored advanced I.C. engine $R$ and $D$ projects since 1977 . For example, the DARPA/GTEC engine project 17 resulted in excellent efficiency and unprecedented power densities from a high-speed diesel test rig, The TACOM/Cummins Adiabatic Diesel Engine program 16 has resulted in the successful demonstration of ceramic and other types of heat-insulating parts in a turbo-compounded diesel engine. This includes demonstration of a sustained cruise BSFC of 0.285 lbs/bhp-hr. Department of Energy (DOE)-sponsored diesel technology efforts for highway vehicles are also technically related. The Navy/USMC/CurtissWright multi-fuel rotary marine engine project resulted in a sophisticated stratified-charge combustion system, which has demonstrated true multifuel capability, together with efficiencies rivaling some diesel engines. Hardware from this project was used to generate design data in the early part of the ongoing NASA/Curtiss-

Wright/Deere aircraft rotary test engine contract. In so doing, it demonstrated power density and minimum BSFC levels closely approaching the present target values. 8

Conclusions based on the above-mentioned programs are:

(1) A significant level of advanced, highoutput I.C. engine research has been sponsored by the DOD and NASA since 1977. By combining the applicable portions of various programs, it appears that the value of this investment may approximate a $\$ 30$ million to $\$ 50$ million down payment towards advanced aircraft I.C. engine technology.

(2) While some of the above efforts are still ongoing, the collective results to date strongly indicate that the performance levels projected in the early NASA-sponsored I.C. engine studies can very probably be met. The technical credibility of the advanced aircraft I.C. engine concept has advanced from essentially zero in 1977 , to the point where laboratory demonstrations approaching the very attractive predicted BSFC and power density levels had occurred by 1984 .

(3) Although the use of advanced I:C. engines for aviation was initially viewed with skepticism by many segments of industry, those most directly concerned have become highly supportive because of the successful confirmatory experimental efforts referred to above. To mention but one example, Deere and Company has recently undertaken a major and long-term commitment to rotary engine technology.

(4) Although the Government investment since 1977 in this area is substantial in absolute terms, it is small considering or compared to:

(a) The preceding 25 to 30 years of total neglect;

(b) The large expenditures that have been (and continue to be) invested in competing powerplant types; and

(c) The magnitude of work remaining to achieve practical commercial or military utilization of this emerging new technology.

In summary, the fact that so much has been accomplished in a relatively brief time and with 1 imited resources, suggests that aircraft I.C. engine technology is both a highly cost-effective research area, and one that wili soon be ready for a second phase of intensified efforts. The logical next step, as viewed here, is the construction and evaluation (by an aircraft engine manufacturer) of flight-type, turbocharged, multi-cylinder or multirotor test bed engines which are more representative of a potential product. Given adequate resources, the sequence of events could be as illustrated in Fig. 31. The two bars at the upper left represent the two ongoing NASA experimental efforts concerning rotary and diesel engines. (For simplicity, the similarly intended, DOD funded "ADEPT" project is included with the NASA diesel work.) It can be expected that both types of engine will have achieved full-performance operation by 1985 . Either or both could then embark upon programs of testing advanced components and refining the cycle match between experimental rig engine input/output conditions and computer-generated turbocharger characteristics. The shaded bar, labeled "Technology Enablement", represents the intensified second phase mentioned above. Contractor estimates indicate that a substantial additional investment for each core engine and the advanced turbocharger, would be required above the ongoing, fundamental-type activities. Beginning with technological readiness in 1986, this phase

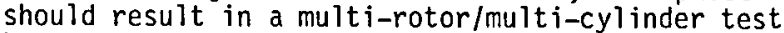
bed engine running about midway through the 3 to 5 year enablement program. Towards the end of this period, it is felt that technical risks will have 
been sufficiently understood and reduced to the point where industry commitments to product engine development programs could become feasible. Thus, new engines of the type described here could be certified and commercially available by the early to mid 1990 's.

\section{Concluding Remarks}

In closing, the crucial role of the "Technology Enablement" process illustrated in Fig. 31 should be emphasized once more. It will be recalled that substantial Government $R$ and $D$ investments since 1977 have resulted in significant progress towards the generic technologies for several advanced I.C. engine concepts. In at least one case, this has directly resulted in a large private-sector commitment, by a major engine manufacturer, to further pursue the appropriate technologies. At present, this comitment exists with a view towards several military and industrial application areas, but not light aircraft powerplants as such. To take advantage of the rapidly expanding base of new technology in this area, the further involvement of the light-aviation community is required. What is needed now is a way to expedite the transfer of new engine technology from a generic research basis into an aviation-oriented environment. The "Technology Enablement" phase shown in Fig. 31 is the current NASA plan for facilitating this process. It is intended to enable one or more of the established aircraft engine manufacturers to become familiar with and begin contributing to the new technologies, with minimal risk initially. Without this long-term NASAindustry commitment, it is unlikely that the new technologies described herein will be implemented in the time and manner that would benefit the U.S. aviation industry.

\section{References}

1. Stuckas, K. J., "Advanced Technology SparkIgnition Aircraft Piston Engine Design Study," November 1980, NASA CR-165162.

2. Brouwers, A. P., "A 150 and $300 \mathrm{~kW}$ Lightweight Diesel Aircraft Engine Design Study," Teledyne Continental Motors, Muskegon, MI, Rpt. 756 Apr. 1980. (NASA CR-3261). Brouwers, A. P., "Design Study: A $186 \mathrm{~kW}$ Lightweight Diesei" Aircraft Engine," Teledyne Continental Motors, Muskegon, MI, Apr. 1980 (NASA CR-3260).

3. Badgley, P., Berkowitz, M., Jones, C., Myers, D., Norwood, E., Pratt, W. B., Mueller, A., Ellis, D. R., Huggins, G. and Hembrey, J. H., "Advanced Stratified-Charge Rotary Aircraft Engine Design Study," Curtiss-Wright, WoodRidge, NJ, CW-WR-81.021, Jan. 1982, (NASA CR-165398).

4. Rezy, B. J., Stuckas, K. J., Tucker, J. R. and Meyers, J. F., "Concepts for Reducing Exhaust Emissions and Fuel Consumption of the Aircraft Piston Engine," SAE Paper 790605, Apr. 1979.

5. Blackaller, D. L., "Development and Application of a Liquid-Cooled V-8 Piston Engine for General Aviation Aircraft, "AIAA Paper 83-1342, June 1983.
6. Moynihan, M. E., Berenyi, S. G. and Brouwers, A. P., "An Update on High Output Lightweight Diesel Engines for Aircraft Applications," AIAA Paper 83-1339, June 1983.

7. Jones, C., "An Update of Applicable Automotive Engine Rotary Stratified Charge Developments," SAE Paper 820347, Feb. 1982.

8. Jones, C., Ellis, D. R. and Meng, P. R., "Multi-Fuel Rotary Engine for General Aviation Aircraft," AIAA Paper 83-1340, June 1983.

9. Strack, W. C., "New Opportunities for Future Small Civil Turbine Engines - Overviewing the GATE Studies," NASA TM-79073, 1979.

10. Wickenheiser, T. J., Knip, G., Plencner, R. M. and Strack, W. C., "Comparisons of Four Alternative Powerplant Types for Future General Aviation Aircraft," NASA TM-81584, 1980.

11. Zmroczek, L. A., "Advanced General Aviation Engine/Airframe Integration Study, "Beech Aircraft Corporation, Wichita, KS, Apr. 1983 (NASA CR-165565).

12. Huggins, G. L. and Ellis, D. R., "Advanced General Aviation Comparative Engine/Airframe Integration Study," Cessna Aircraft Company, Wichita, KS, Cessna AD-217, Sept. 1981, (NASA CR-165564).

13. Brouwers, A. P., "Lightweight Diesel Engine Designs for Commuter Type Aircraft, "Teledyne Continental Motors, Muskegon, MI, Report-995, July 1981, (NASA CR-165470).

14. Berkowitz, M., Jones C. and Myers, D., "Study of Advanced Rotary Combustion Engines for Commuter Aircraft," Curtiss-Wright Corp., Wood-Ridge, NJ, CW-WR-81-022f, Feb. 1983, (NASA CR-165399).

15. Wilsted, H. D., "Preliminary Survey of Possible Use of the Compound Adiabatic Diesel Engines for Helicopters," SAE Paper 820432, Feb. 1982 .

16. Glance, P. C. and Bryzik, W., "US Army Tank-Automotive Command (TACOM) Adiabatic Engine Program," AIAA Paper 83-1283, June 1983.

17. Castor, J. G., "Compound Cycle Turbofan Engine," AIAA Paper 83-1338, June 1983.

18. Flower, A. R., "World 0 il Production," Scientific American, Vol. 238, No. 3, Mar. 1978, pp. 42-49.

19. Patterson, D. J., "Aviation Gasolines and Future Alternatives," NASA CP-2267, 1983.

20. Schock, H. J., Rice, W. J. and Meng, P. R., "Experimental Analysis of IMEP in a Rotary Combustion Engine - Indicated Mean Effective Pressure," SAE Paper 810150, Feb. 1981.

21. Rice, W. J., "Development of an Instrument for Real-Time Computation of Indicated Mean Effective Pressure," NASA TP-2238, 1984. 
22. Rice, W. J. and Birchenough, A. G., "Modular Instrumentation System for Real-Time Measurements and Control on Reciprocating Engines," NASA TP-1757, Nov. 1980.

23. Knoll, J., Vilmann, C. R., Schock, H. J. and Stumpf, R. P., "A Dynamic Analys is of Rotary Combustion Engine Seals," NASA TM-83536, 1984.

24. Fusaro, R.L., "Polyimides Formulated From a Partially Fluorinated Diamine for Aerospace Tribological Applications," NASA TM-83339, 1983.

25. Culy, D. G., Heldenabrand, R. W. and Richardson, N. R., Garrett Turbine Engine Company, "Advanced Turbocharger Design Study Program," Garrett Turbine Engine Co., Phoenix, $A Z$, GTEC 21-4498, Jan 1984, (NASA CR-174633).

26. Meng, P. R., Rice, W. J., Schock, H. J. and Pringle, D. P., "Preliminary Results on Performance Testing of a Turbocharged Rotary Combustion Engine," SAE Paper 820354, Feb. 1982 .
27. Wilkinson, P. H., "Aircraft Diesels," Pitman Publishing Corp., New York, 1940.

28. Shih, T. I. P., Smith, G. E. and Springer, G. S., "Numerical Simulation of the Flow and Fuel-Air Mixing in an Axisymmetric PistonCylinder Arrangement," NASA TM-83011, 1982.

29. Schock, H. J., Sosoka, D. J. and Ramos, J. I., "Numerical Studies of the Formation and Destruction of Vortices in a Motored FourStroke Piston-Cylinder Configuration," AIAA Paper 83-0497, Jan. 1983.

30. Schock, H. J., Regan, C. A., Rice, W. J. and Chlebecek, R. A., "Mult icomponent Velocity Measurement in a Piston-Cylinder Configuration Using Laser Velocimetry," NASA TM-83534, 1983.

31. Schock, H. J., Case, S. and Konicek, L., "Window Aberration Correction in Laser Velocimetry Using Mult if aceted Holographic Optical Elements," Applied Optics Vol. 23, Mar. 1, 1984, pp 752-756. 
TABLE I. - ADVANCED ENGINE COMPARISON PURE HELICOPTER VEHICLE [Relative values $(A T E=1$ ) for a $2 \mathrm{hr}$ $135 \mathrm{n}$ mi mission.]

\begin{tabular}{|l|c|c|c|}
\hline & $\begin{array}{c}\text { Turbine } \\
\text { ATE }\end{array}$ & $\begin{array}{c}\text { Regenerative } \\
\text { (RCVPT) }\end{array}$ & $\begin{array}{c}\text { Compound } \\
\text { (CCTDE) }\end{array}$ \\
\hline IRP SL/STD & 1.000 & 1.003 & 0.717 \\
XMSN rated hp & .872 & .875 & .717 \\
Engine-dry weight & 1.000 & 1.441 & 1.663 \\
& 1.000 & 1.038 & 1.004 \\
Empty weight & 1.000 & .796 & .584 \\
Fuel burned & 1.000 & 1.000 & 1.000 \\
Payload & 1.000 & 1.000 & .950 \\
Gross weight & & \multicolumn{3}{|c}{} \\
\hline
\end{tabular}


DESCRIPTION/OBJECTIVE:

AN R\&T BASE PROGRAM TO ESTABLISH THE GENERIC TECHNOLOGY BASE FOR HIGHLY ADVANCED ROTARY AND DIESEL ENGINES FOR FUTURE BUSINESS/COMMUTER/GENERAL AVIATION, HELICOPTERS AND RELATED APPLICATIONS

PAYOFF/JUSTIFICATION:

- MAJOR FUEL SAVINGS

- LOW COST POTENTIAL

- MATCH INDUSTRY NEEDS AND CAPACITY

APPROACH:

-ROTARY MULTI-FUEL ENGINES

- TWO-STROKE DIESEL ENGINES

- BASIC R\&T VIA IN-HOUSE AND GRANTS

- CONTRACTS FOR ENGINE R\&D

TECHNICAL THRUSTS:

- COMPUTERIZED CYCLEIPROCESS MODELS

- ADVANCED COMBUSTION, IGNITION AND FUEL-INJECTION TECHNOLOGIES

- ADVANCED MATERIAL, COMPONENT AND TRIBOLOGICAL TECHNOLOGIES

- TECHNOLOGY VALIDATION EXPERIMENTS WITH BREADBOARD ENGINE RIGS

Figure 1. - Intermittent combustion (I. C. ) engine research. 


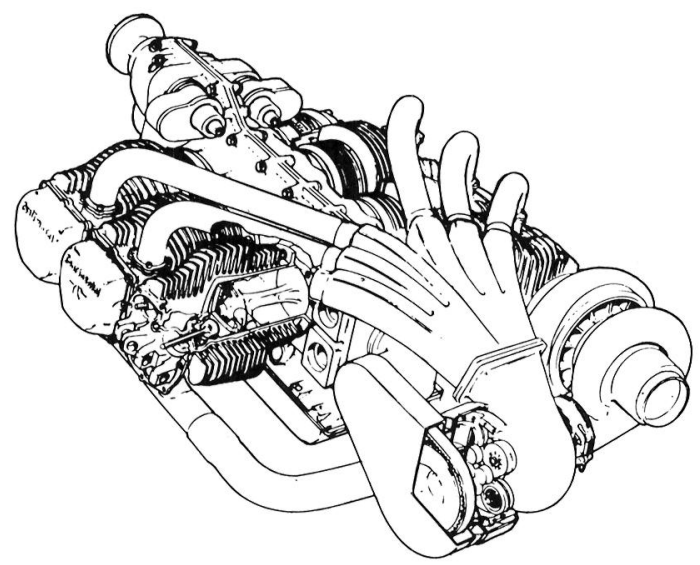

SPARK IGNITION RECIPROCATING ENGINE $\mathrm{SFC}=0.33 \mathrm{lb} / \mathrm{hp}-\mathrm{hr}$ $\mathrm{SP} . \mathrm{wt} .=1.16 \mathrm{lb} / \mathrm{hp}$ *TURBOCOMPOUNDED

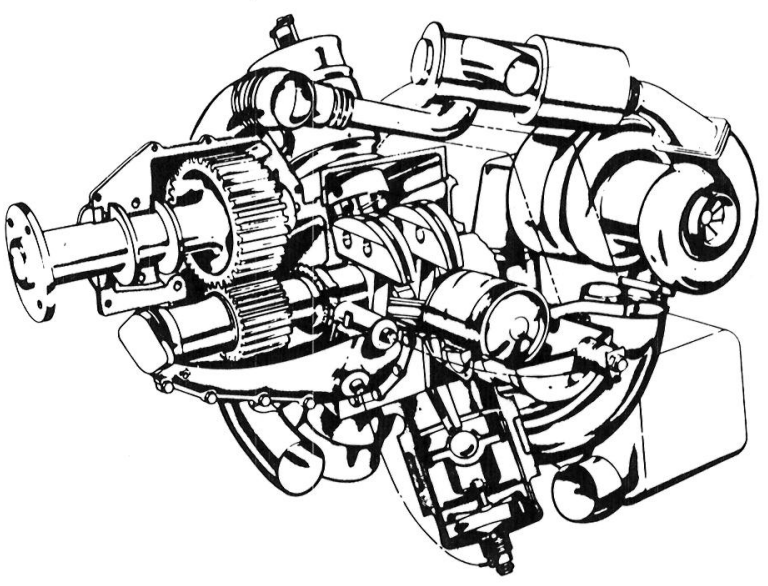

LIGHTWEIGHT DIESEL ENGINE $\mathrm{SFC}=0.32 \mathrm{lb} / \mathrm{hp}-\mathrm{hr}$ SP. wt. $=1.02 \mathrm{lb} / \mathrm{hp}$

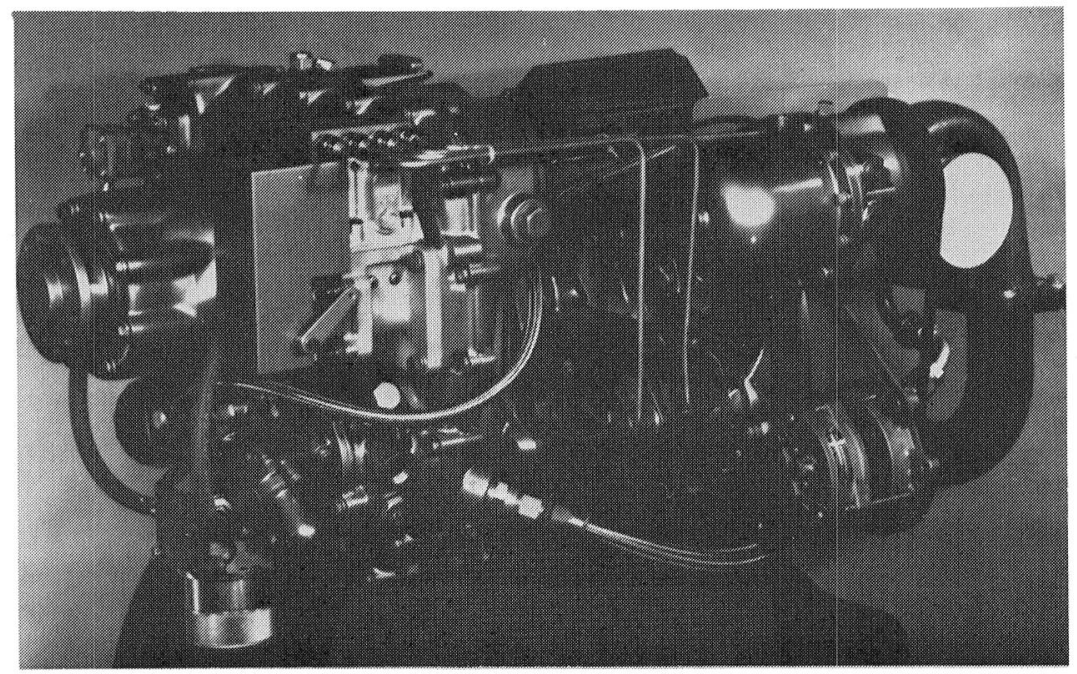

ROTARY ENGINE

$\mathrm{SFC}=0.35 \mathrm{lb} / \mathrm{hp}-\mathrm{hr}$

SP. wt. $=0.80 \mathrm{lb} / \mathrm{hp}$

Figure 2. - Advanced technology general aviation engines. 
- LIGHTER

- MORE EFFICIENT

- COMPACT

- LOW DRAg installation

- MULTIFUel

- MORE DURABLE, RELIABLE

- LeSS MAINTENANCE

- LeSS NOISE, VIBRATION

- cleaner

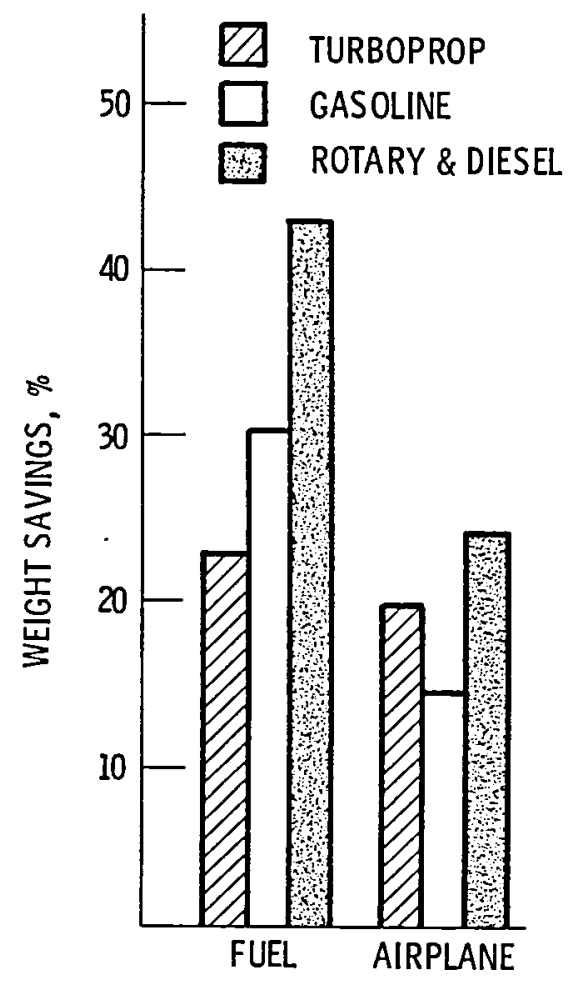

Figure 3. - Advanced propulsion system benefits.

- R\&T EFFORT PRIMARILY LEWIS RESEARCH CENTER IN-HOUSE OR GRANT, FY 84 AND PRIOR YEARS - HIGH SPEED. HIGH BMEP STRATIFIED-CHARGE COMBUSTION

- SEALS AND LUBES

- THERMAL TECHNOLOGY

- TURBOCHARGING/TURBOCOMPOUNDING

- CONTRACT EFFORT (C-W/DEERE) TO DESIGN/BUILD HIGH-OUTPUT ROTARY TEST ENGINE

- C-W FINAL DESIGN REVIEW, SEPTEMBER 1983

- DEERE \& CO. ASSUMES INDUSTRY LEAD ROLE IN ROTARY R\&D, FEBRUARY 1984

- FIRST BUILD, JUNE 1984

- ACCEPTANCE TEST, SEPTEMBER 1984

- COMBINED IN-HOUSE/CONTRACT R\&D PROGRAM, FY 85 AND ON

Figure 4. - Rotary engine R\&T - activity profile. 


\section{OBJECTIVE}

- OBTAIN EFFICIENT, RAPID COMBUSTION AT HIGH POWER DENSITIES

(GET LOTS OF FUEL AND AIR TOGETHER QUICKLY AND BURN THEM FAST)

\section{ELEMENTS}

- INTERNAL AIR MOTIONS

\section{- COMPUTER CODES}

- LDV VALIDATION EXPERIMENTS

- FUEL INJECTION/SPRAY DYNAMICS

- IGNITION PROCESSES

ONGOING/START FY 84

- EVAPORATION/MIXING PHENOMENA FUTURE

- INLET AND EXHAUST FLOWS

- PORTING AND TUNING EFFECTS

- FLAME KINETICS AND PROPAGATION

- WALL EFFECTS

- CATALYSIS

Figure 5. - High speed, high BMEP stratified-charge combustion in rotary engines.

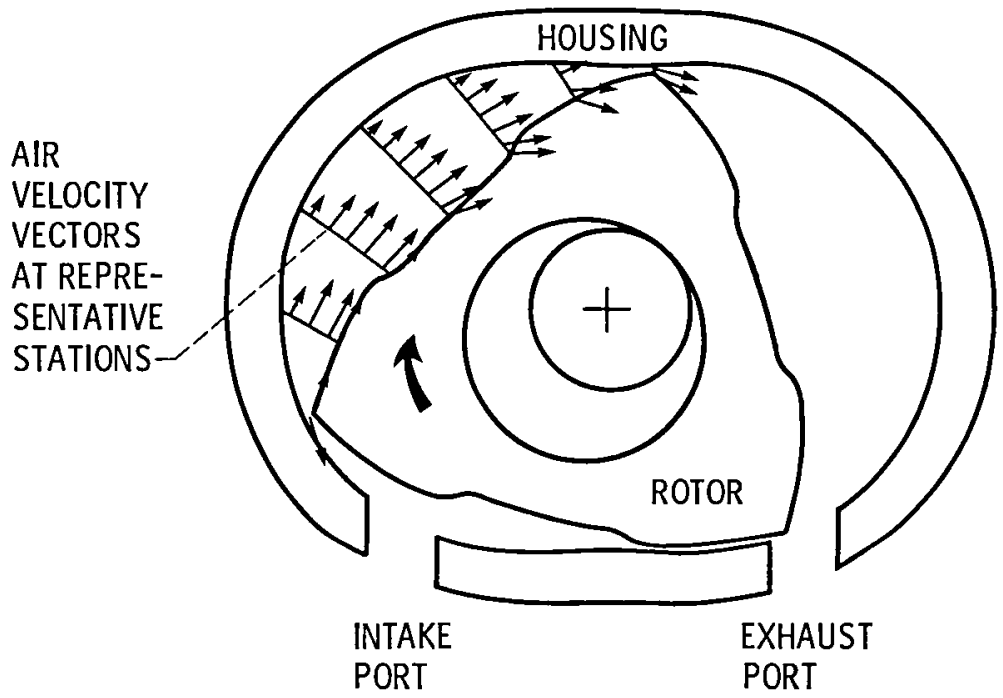

Figure 6. - Rotary engine - airflow model. 


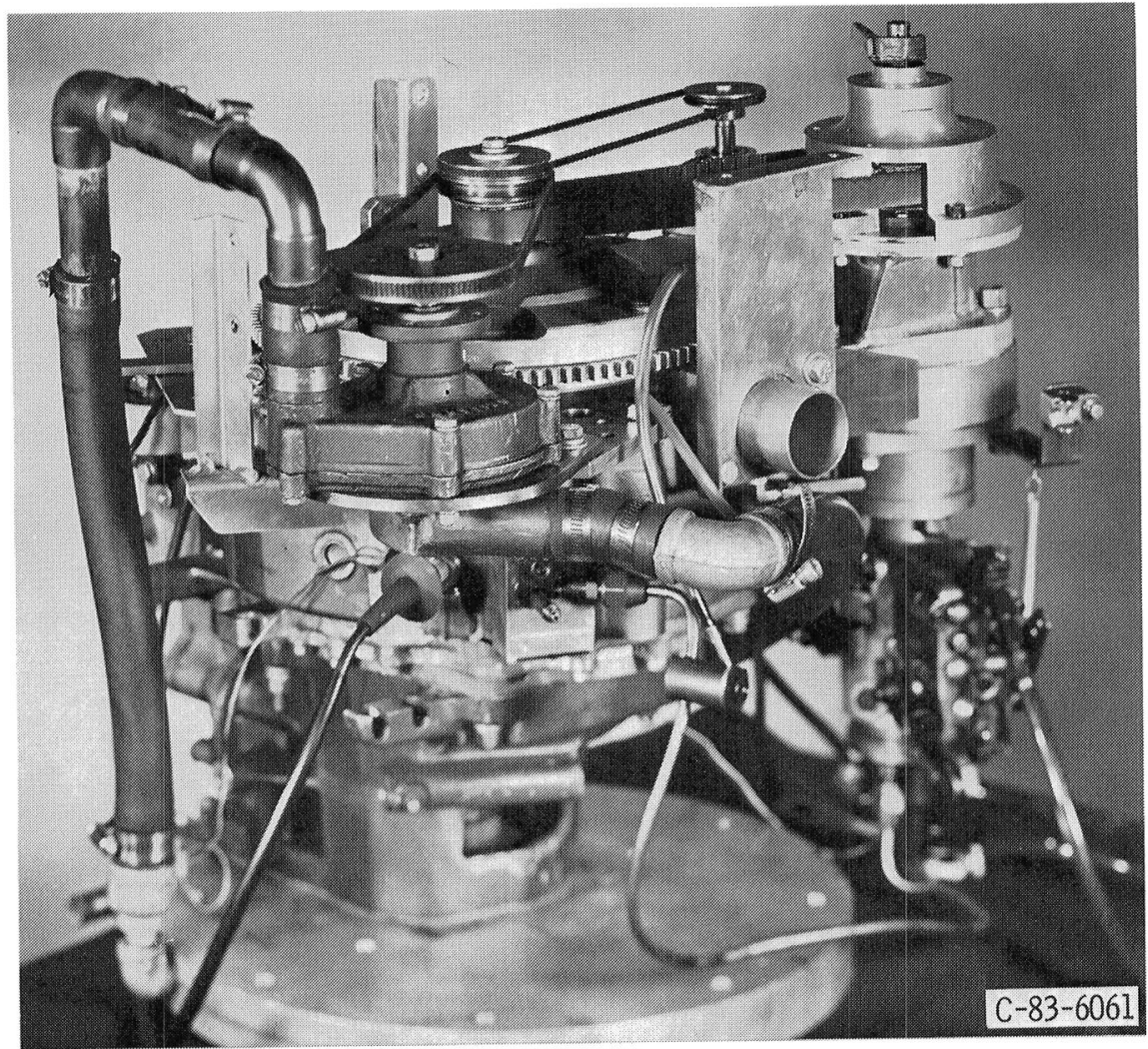

Figure 7. - Stratified charge rotary combustion reseach rig- single rotor OMC engine. 


\section{OBJECTIVES \\ - IMPROVED GAS-SEALING EFFICIENCY AT ALL SPEEDS \\ - REDUCED FRICTION \\ - LOW WEAR RATES \\ ELEMENTS \\ - APEX SEALS \\ - C FIBER IPOLYIMIDE COMPOSITE \\ - SYALON \\ -PSZ \\ - $\mathrm{SI}_{3} \mathrm{~N}_{4}$ \\ - SiC \\ -AERODYNAMIC (GAS-LUBRICATED) \\ - TRIBOLOGY \\ - HIGH TEMPERATURE SYNTHETIC OILS \\ - ANTI-FRICTION BEARINGS \\ - AIR-LUBRICATED ROTOR/PISTON \\ - ROTOR DYNAMICSISTABILIZATION}

Figure 8. - Advanced rotary engine seals and lubrication.

FIN AND DISC FRICTIONI WEAR TESTER

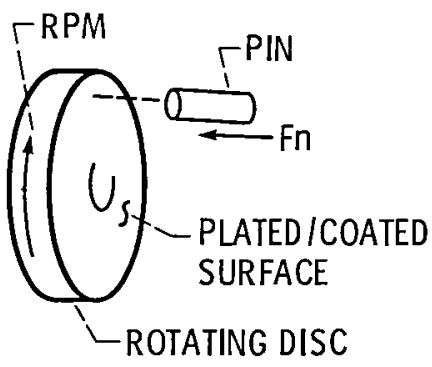

SEAL/SURFACE MATERIAL CANDIDATES

- CARBON/CHROME (MAZDA)

- CLEVITE 300/WC (C-W)

- C-FIBER REINFORCED POLYIMIDE COMPOSITE/CHROME (TRW)

- SYALON/CHROME (LUCAS)

- $\mathrm{Si}_{3} \mathrm{~N} / \mathrm{CHROME}$ (WANKEL)

- SIC/CHROME

- AERO-LIFTOFF

Figure 9. - Apex seal research. 


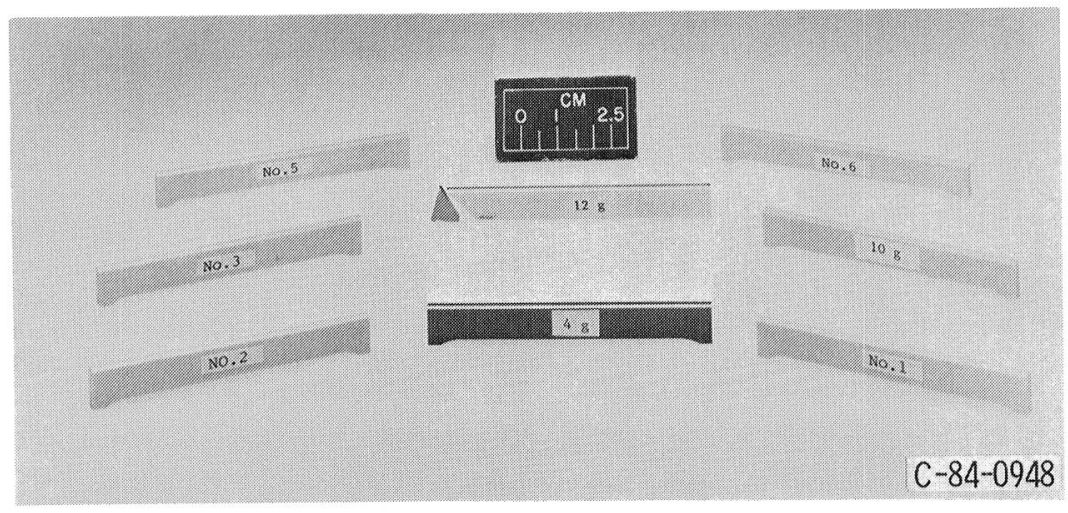

Figure 10. - PSZ apex seals (no.'s 1-6, $10 \mathrm{~g}$.) compared with iron (12g.) and graphite $(4 \mathrm{~g}$.) seals.

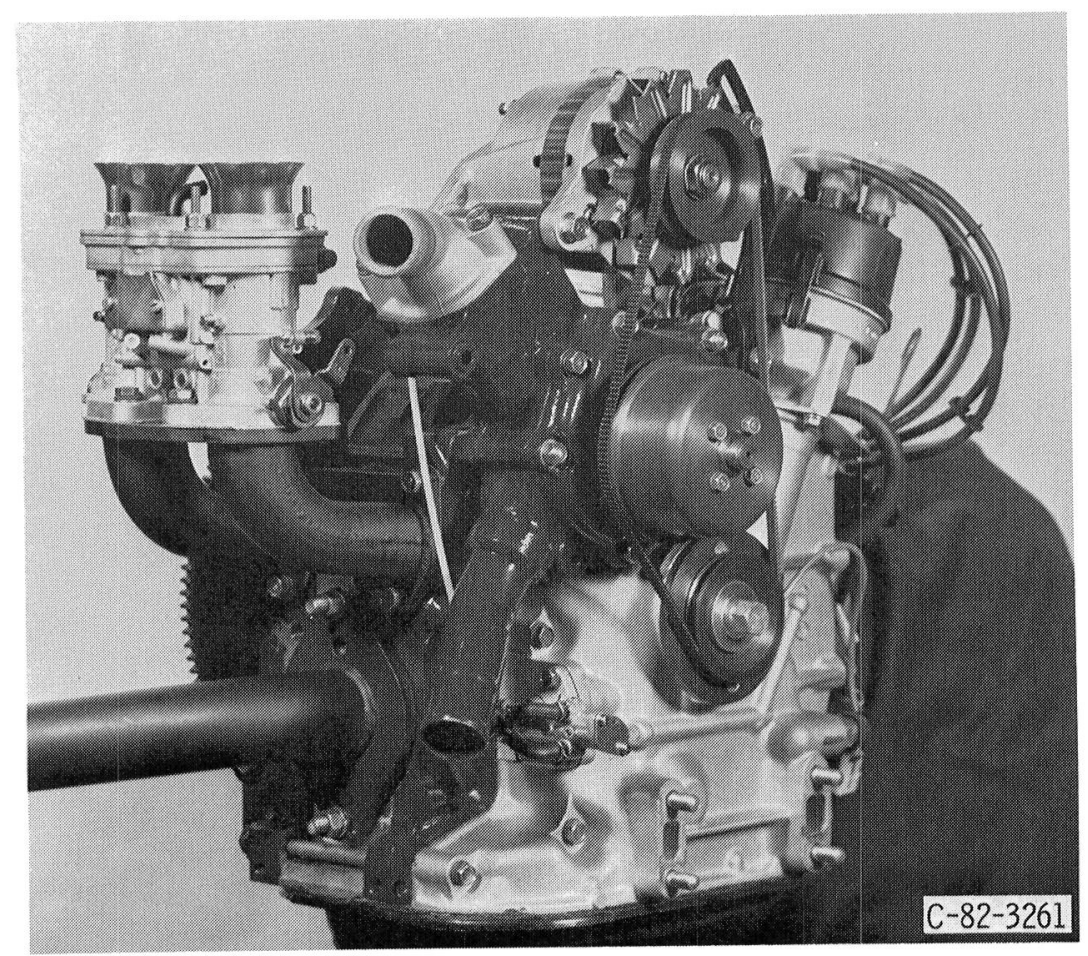

Figure 11. - High output, single-rotor gasoline powered rotary test engine. 


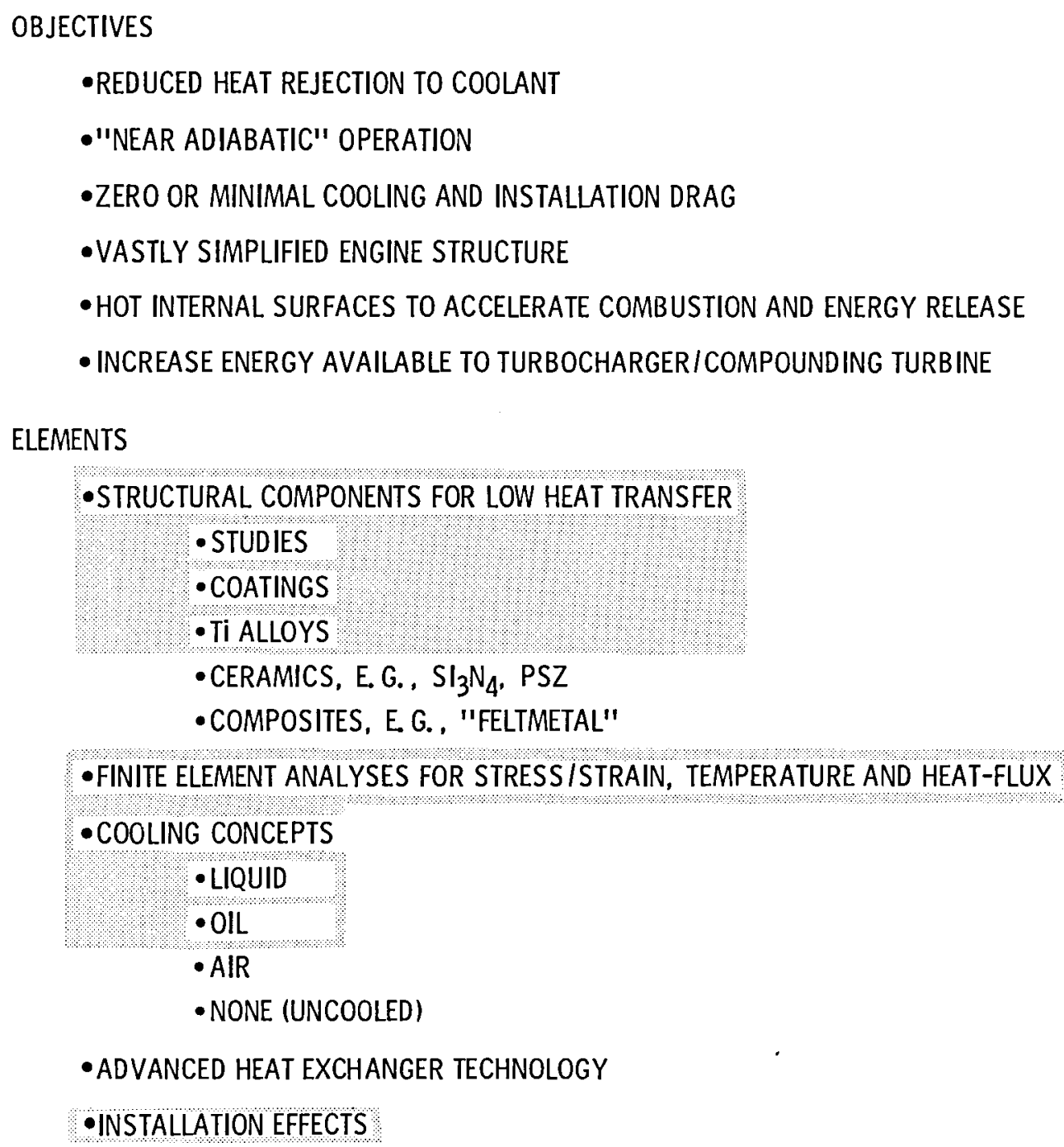

Figure 12. - Thermal technology for rotary engines. 


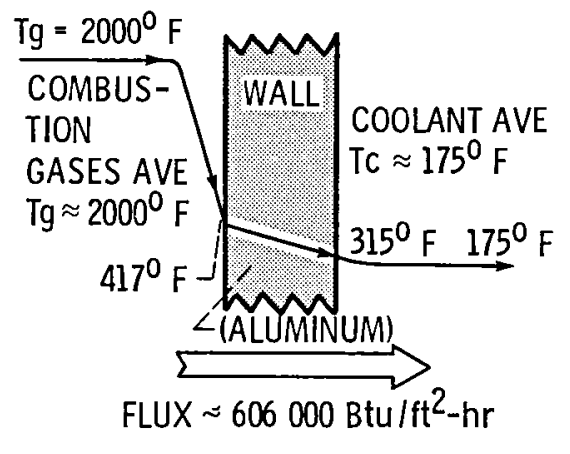

(a) Conventional wall.

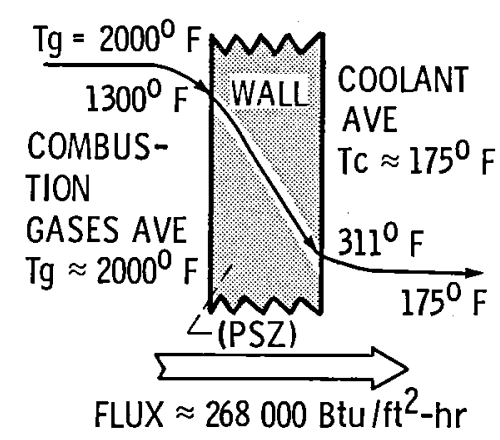

(b) Adiabatic wall.

Figure 13. - Combustion chamber wall temperatures and heat flows.

- OBJECTIVES

- ADVANCED TECHNOLOGY FOR TURBOCHARGERS

- ADVANCED TECHNOLOGY FOR COMPOUNDING SYSTEMS

- ELEMENTS

- STUDIES

- DESIRED TURBOCHARGER CHARACTERISTICS (AS DEFINED BY GTEC STUDY)

- CERAMIC TURBINE WHEEL

- FULL AIR BEARING SUSPENSION

- LIGHTWEIGHT SHEET-METAL TURBINE HOUSING

- IMPROVED COMPONENT EFFICIENCIES

- COMPOUNDING TURBINE (INCLUDED IN TCM ENGINE STUDY)

- NOT COST-EFFECTIVE FOR GENERAL AVIATION

- ESSENTIAL FOR "ADIABATIC" ENGINES

- DETAILED PROGRAM YET TO BE DEFINED (SIMILAR FOR ROTARY OR DIESEL)

Figure 14. - Advanced turbocharger/turbocompounding technology 


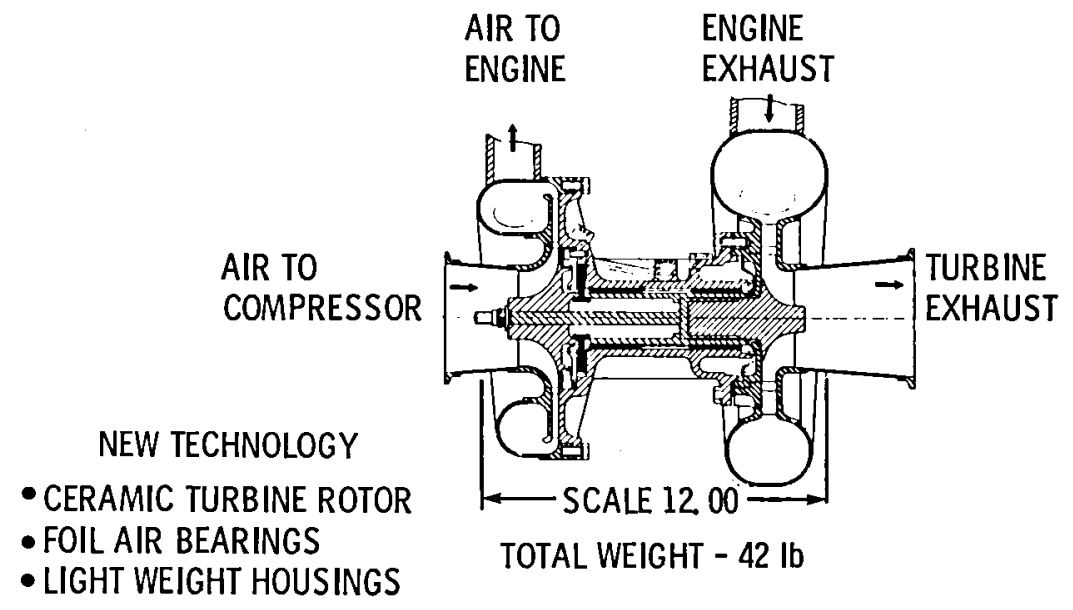

(a) Advanced technology (compression ratio $6.0-2.2 \mathrm{lb} / \mathrm{sec}$ air flow).

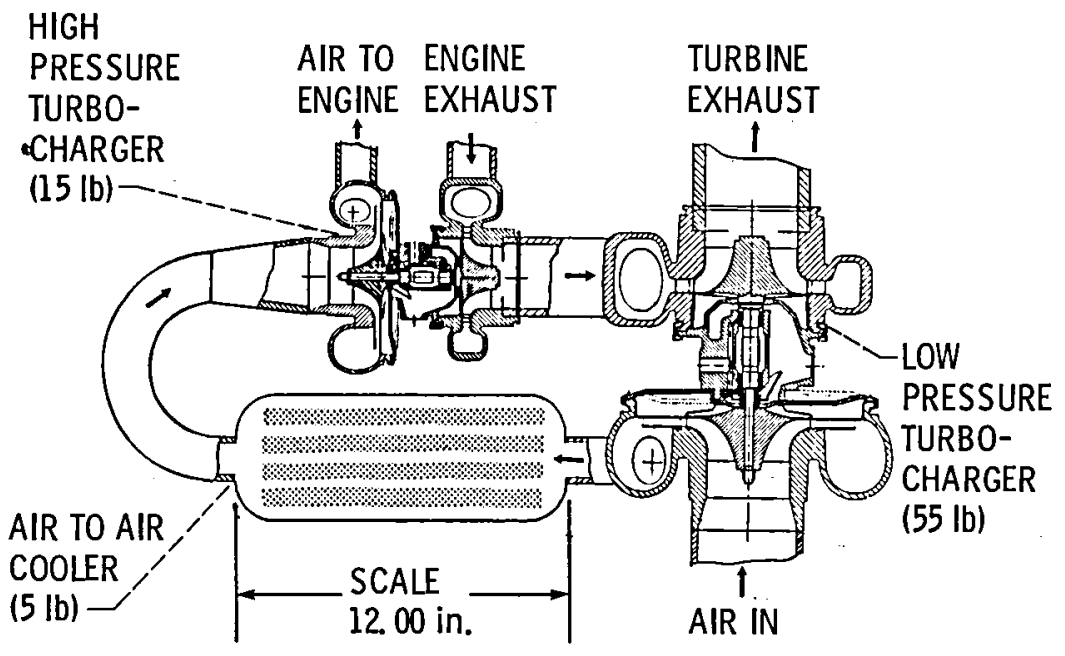

(b) Conventional technology (compression ratio $6.0-22 \mathrm{lb} / \mathrm{sec}$ air flow). Total weight of components less piping $-75 \mathrm{lb}$.

Figure 15. - Turbocharger technology comparison. 
PRIMARILY CONTRACT

- LEWIS RESEARCH CENTER IN-HOUSE BASIC RESEARCH SUPPORT IN FLOW MODELLING AREA

- TELEDYNE GPD CONTRACT:

- SINGLE-CYLINDER R\&T

- UNDER NAY SINCE 1981

- GENERAL AVIATION ORIENTED

- "ADEPT" CONTRACT, GARRETT T. E. C. :

-DOD FUNDED

- AGGRESSIVE TECHNOLOGY GOALS

- SINGLE-CYLINDER R\&T

- MILITARY/ROTORCRAFT ORIENTED

Figure 16. - Diesel engine R\&T - activity profile.

EMPHASIS AREAS

- HIGH SPEED, HIGH BMEP DIESEL COMBUSTION/FUEL INJECTION

- PISTON RING/CYLINDER SEALING, FRICTION, WEAR, AND LUBRICATION

- THERMAL TECHNOLOGY (INSULATIVE COMPONENTS)

- AIR UTILIZATION AND TURBOCHARGING

STATUS

- SUCCESSFULLY COMPLETED DEMONSTRATION OF FULL TAKEOFF POWER (104 ihp) ON SCTE. CONFIRMED MOST MAJOR DESIGN PARAMETERS

- HARDWARE MODIFICATIONS IN PROCESS TO PERMIT OPERATION AT HIGHER TEMPERATURES AND LOWER AIR CONSUMPTION VALUES

- INSULATED HARDWARE WILL BE DESIGNED, PROCURED AND TESTED TO REDUCE HEAT REJECTION AND ATTAIN CYCLE MATCH WITH TURBO

Figure 17. - Diesel single-cylinder test engine (SCTE) - objectives and status. 


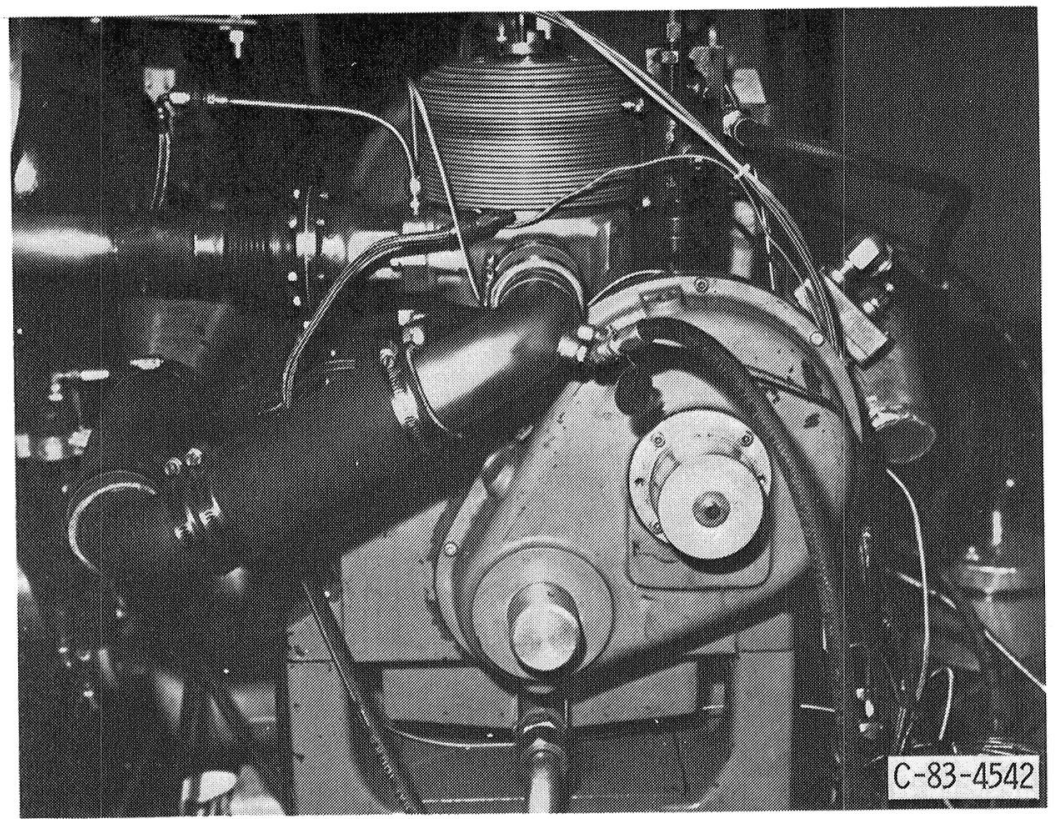

Figure 18. - Two stroke cycle diesel single cylinder test engine. 

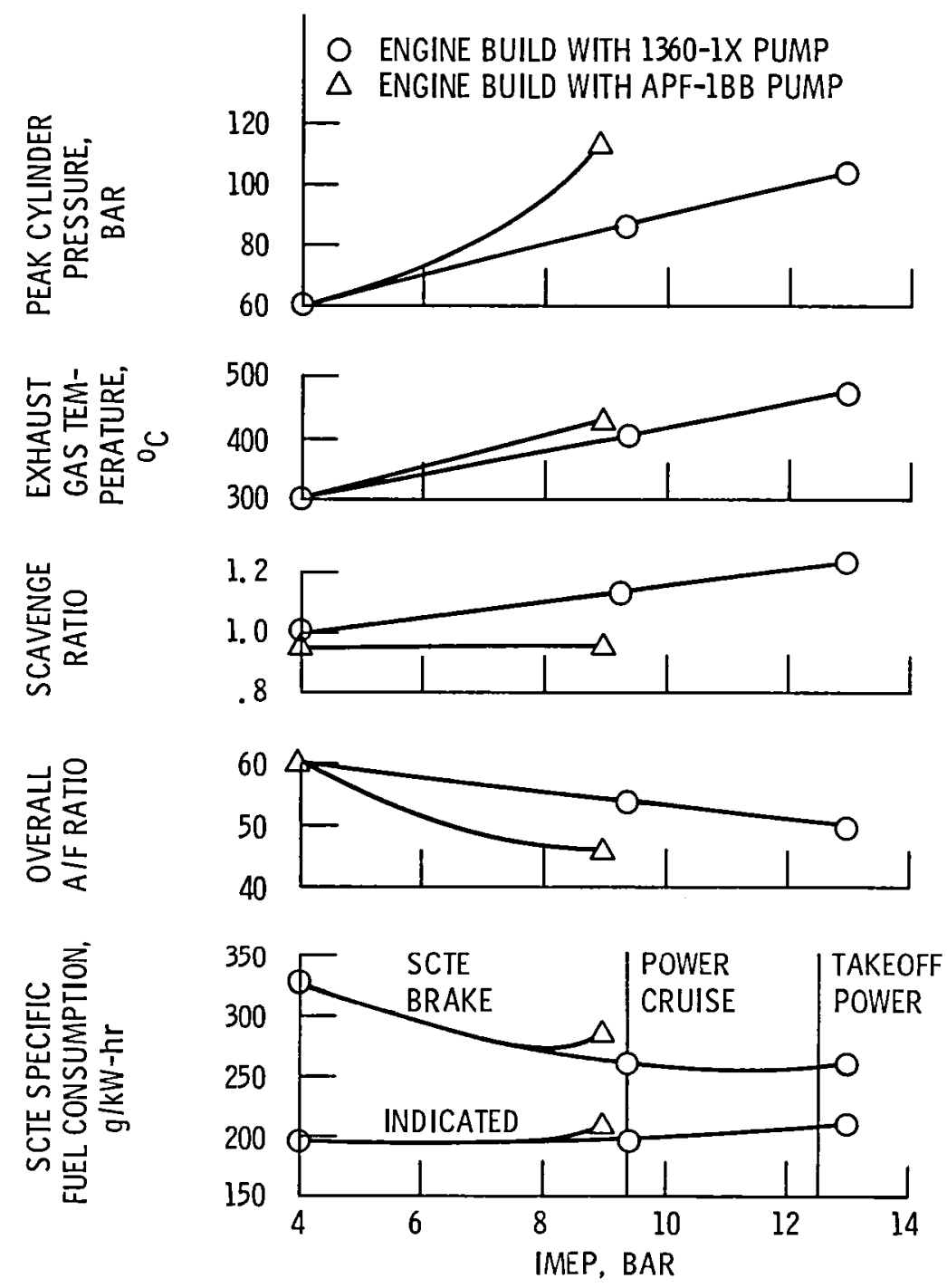

Figure 19. - SCTE part load performance at $3500 \mathrm{rpm}$. 


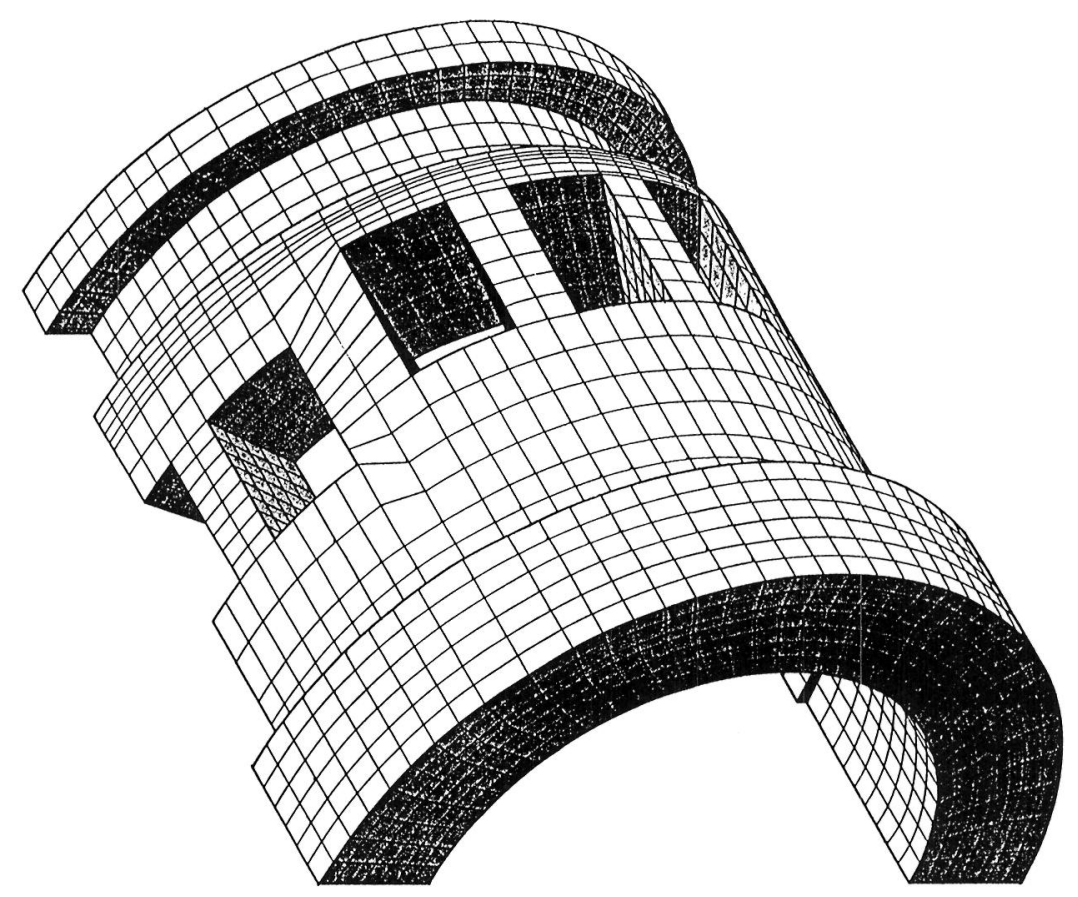

Figure 20. - Finite element grid for cylinder liner.

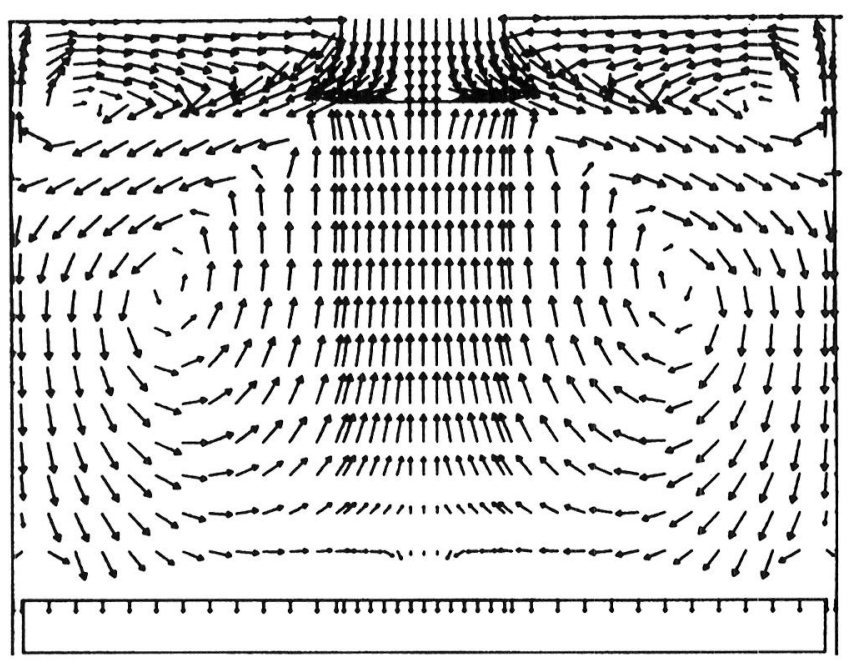

Figure 21. - Results of flowfield simulation for an axisymmetric piston-cylinder configuration. Cycle 1; crank angle, $78^{\circ}$; rpm, 1000.0; comparative ratio, 7.0. 


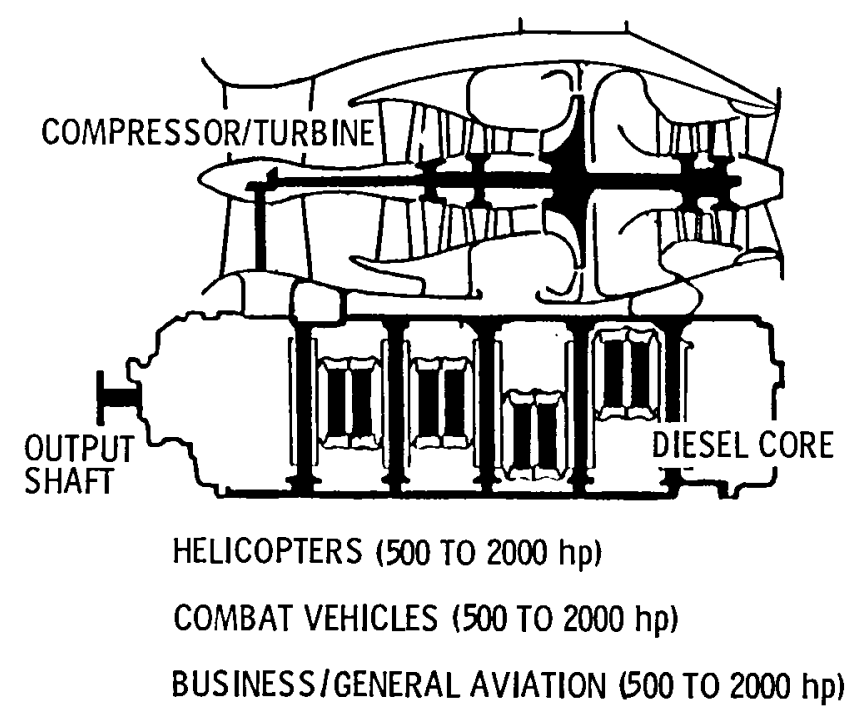

Figure 22. - Joint program interests in compound diesel technology.

1977: PROGRAM INITIATED AS COMPOUND CYCLE TURBOFAN ENGINE (CCTE) FOR AF MISSION (SHORT LIFE UNMANNED APPLICATION)

- DARPA ORDER NUMBER 3430

- AF CONTRACT 3365-77-0391

1981-82: PROGRAM STOPPED - CHANGE IN AF PRIORITY

ACHIEVEMENT DEMONSTRATED IN TWO-STROKE CYCLE:

- SPEED

$8000 \mathrm{rpm}$

- PONER DENSITY

$7.2 \mathrm{hp} / \mathrm{in}^{3}$

- INJECTOR PRESSURE

18000 psi

- BRAKE MEAN EFFECTIVE PRESSURE

385 psi

Figure 23. - Background for ADEPT. 
- LOW CRUISE SFC: 0.29 TO $0.35 \mathrm{lb} / \mathrm{hp}-\mathrm{hr}$ (LARGE IMPROVEMENT)

- INCREASED RANGE X PAYLOAD PRODUCT

- REDUCED SIZE/WEIGHT OF AIRCRAFT FOR GIVEN MISSION

- LOW ENGINE VOLUME:

- HIGH POWER DENSITY: OVER $4.8 \mathrm{hp} / \mathrm{in}^{3}$

(VIA OPERATION AT $6000 \mathrm{rpm}$ AND 366 psi BMEP IN TWO-STROKE CYCLE)

- LOW SPECIFIC WEIGHT: $0.62 \mathrm{lb} / \mathrm{hp}$

- LOW EXHAUST GAS TEMPERATURE: $550^{\circ} \mathrm{F}$ TO $750^{\circ} \mathrm{F}$

- LOW IDLE FUEL CONSUMPTION

- RAPID RESPONSE RATE

- POWER BOOST/EMERGENCY: UP TO 40 PERCENT

Figure 24. - Benefits of ADEPT/CCTDE. 
ADEPT

$1984-1986$

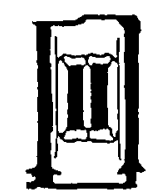

SINGLE-CYLINDER RIG

\section{OBJECTIVES}

HIGH SPEED FUEL

INJECTION/COMBUSTION

PISTON RINGS

INTRA-CYLINDER GAS

DYNAMICS

MATERIALS AND LUBRICATION

DESIGN AND APPLICATION

STUDIES (CCTDE)
CCTDE

$1987-1991$

THREE-CYLINDER RIG

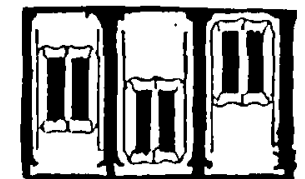

OBJECTIVES

CONTINUE/EXTEND

SINGLE-CYLINDER

OBJECTIVES

INTER-CYLINDER GAS

DYNAMICS

BALANCE AND VIBRATION

COOLING
"BREADBOARD" ENGINE

OBJECTIVES

TURBOMACHINERY

AND ACCESSORIES

SYSTEM FACTORS

INSTALLATION FACTORS

ALL-UP PERFORMANCE

APPLICATIONS

HELICOPTERS

BUSINESS/COMMUTERI

GENERAL AVIATION

TANKS, APU'S, AND

OTHER

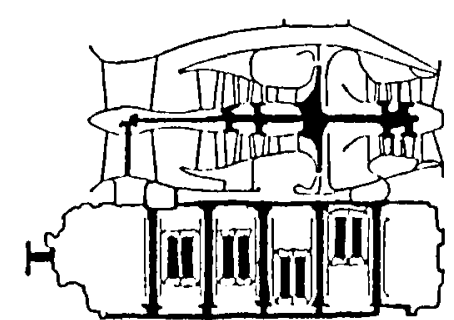

Figure 25. - Technical thrusts - ADEPT and CCTDE. 


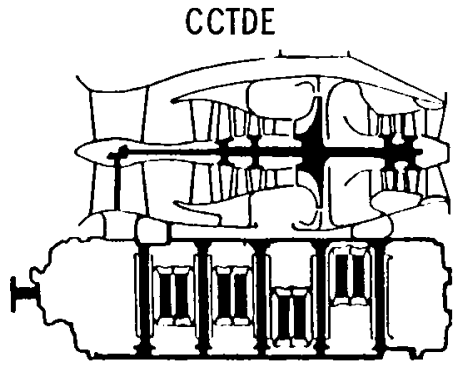

LENGTH: 44.4 in. WIDTH: $26.0 \mathrm{in}$. HEIGHT: 26.0 in. WEIGHT: 750 TO $930 \mathrm{lb}$

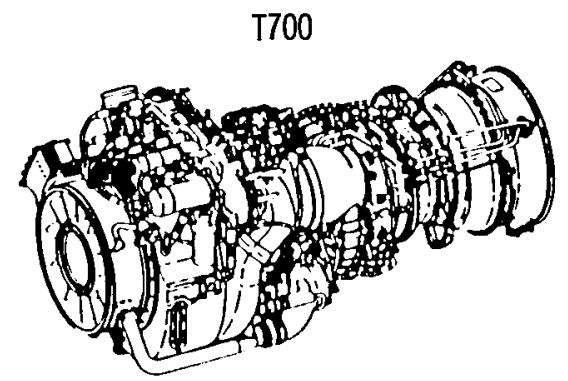

LENGTH: $46.5 \mathrm{in}$. WIDTH: $25.0 \mathrm{in}$. HEIGHT: 23.0 in. WEIGHT: $427 \mathrm{lb}$

Figure 26. - Size comparison (1500 hp).

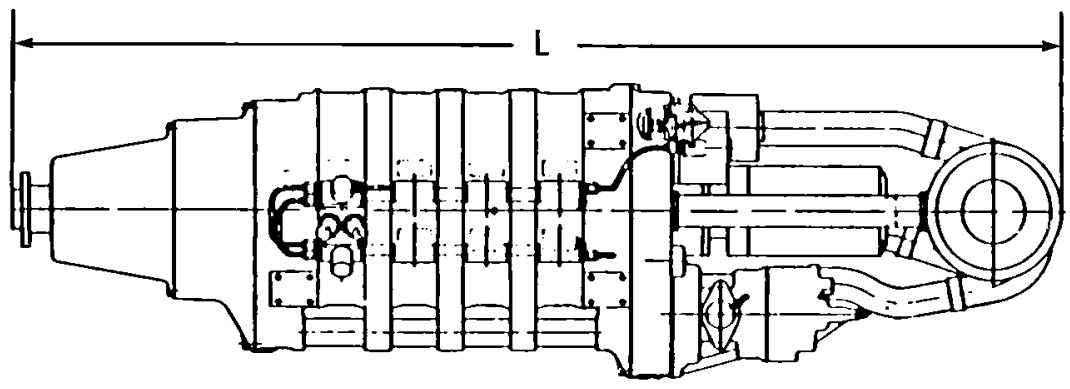

T. 0. HP LENGTH, DIAMETER, WEIGHT, BSFC AT CRUISE, in. in. $\quad \mathrm{lb} \quad \mathrm{lb} / \mathrm{bhp}-\mathrm{hr}$

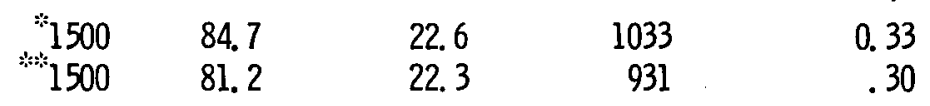

" CONVENTIONAL COOLING

"MINIMUM HEAT REJECTION CYCLE

Figure 27. - Rotary turbocompound aircraft engine. 


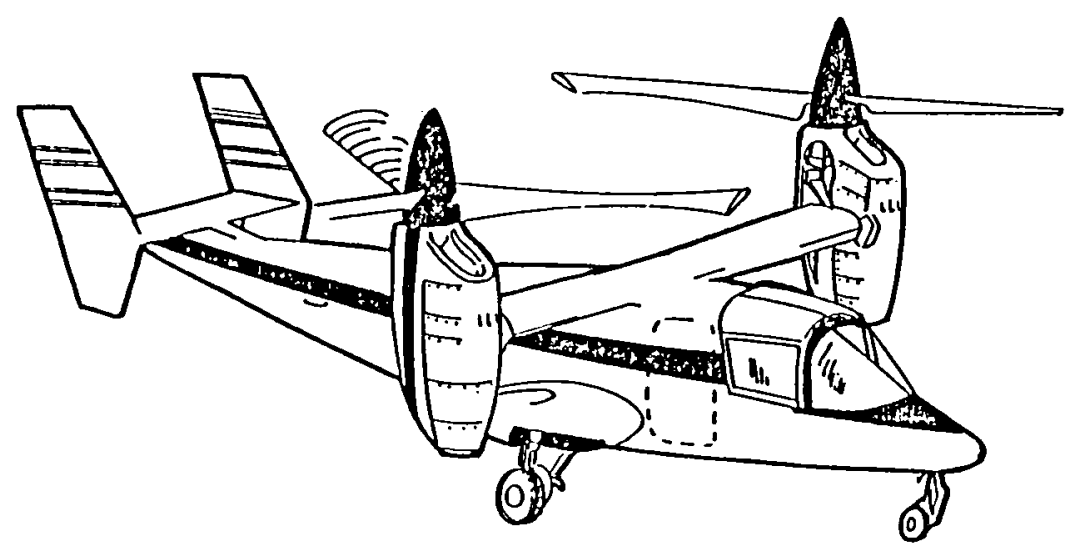

Figure 28. - Tilt-rotor configuration.
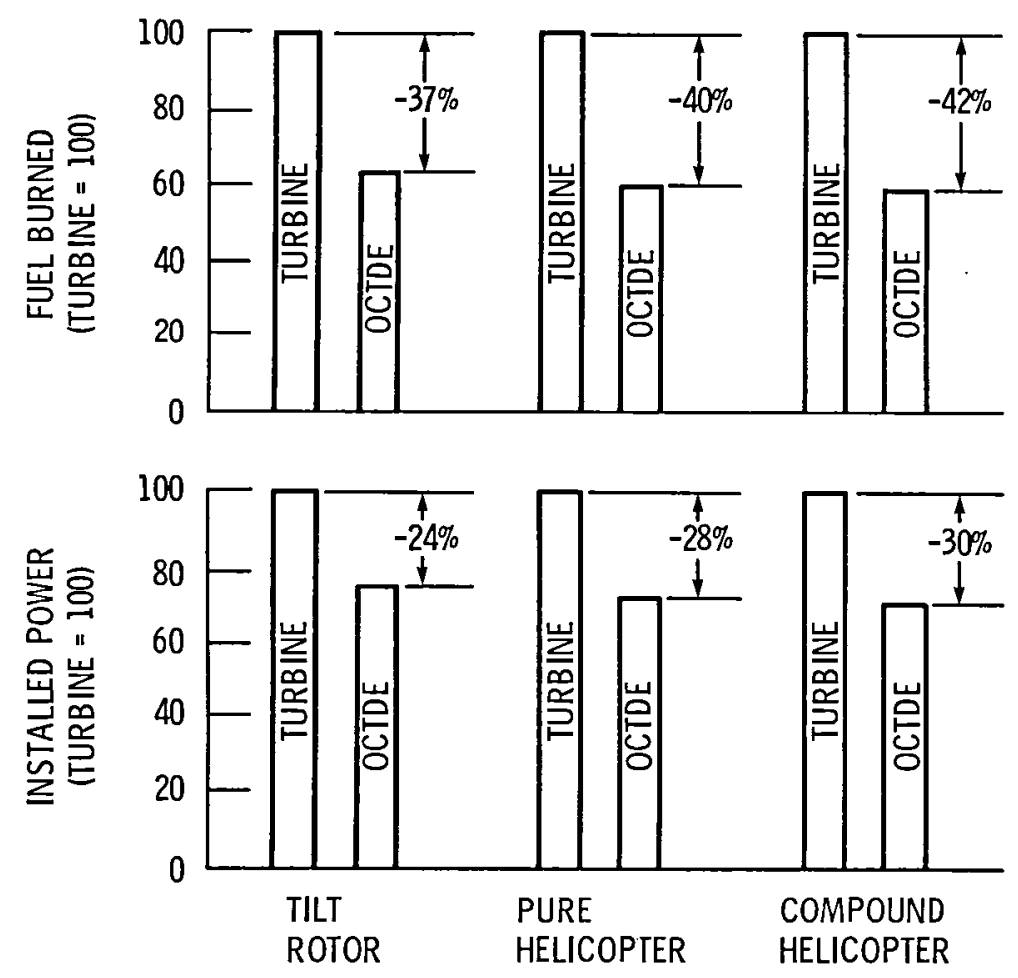

Figure 29. - Helicopter performance comparison: turbine versus CCTDE (fuel and power requirements). 
BASELINE

$\sim 1.6 \mathrm{Ib} / \mathrm{hp} ; 0.45 \mathrm{BSFC}$

- HIGH SPEED, HIGH BMEP STRATIFIED -CHARGE COMBUSTION (MULTI-FUEL CAPABILITY)

- ADVANCED SEALS AND LUBRICATION (INCLUD ING FRICTION/WEAR CONSIDERATIONS)

COMPETITIVE VIABILITY

$\sim 1 \mathrm{lb} / \mathrm{hp} ; 0.38 \mathrm{BSFC}$

- THERMAL TECHNOLOGY FOR REDUCED HEAT REJECTION AND COOLING DRAG

- ADVANCED TURBOCHARGER TECHNOLOGY

SUPERIORITY

$\sim 0.75 \mathrm{lb} / \mathrm{hp} ; 0.33-0.35 \mathrm{BSFC}$

- "ADIABATIC" OPERATION

- TURBOCOMPOUNDING TECHNOLOGY

CONTINUING GROWTH

$\sim 0.6 \mathrm{lb} / \mathrm{hp} ; 0.3 \mathrm{BSFC}$

Figure 30. - Summary: major technical thrusts.

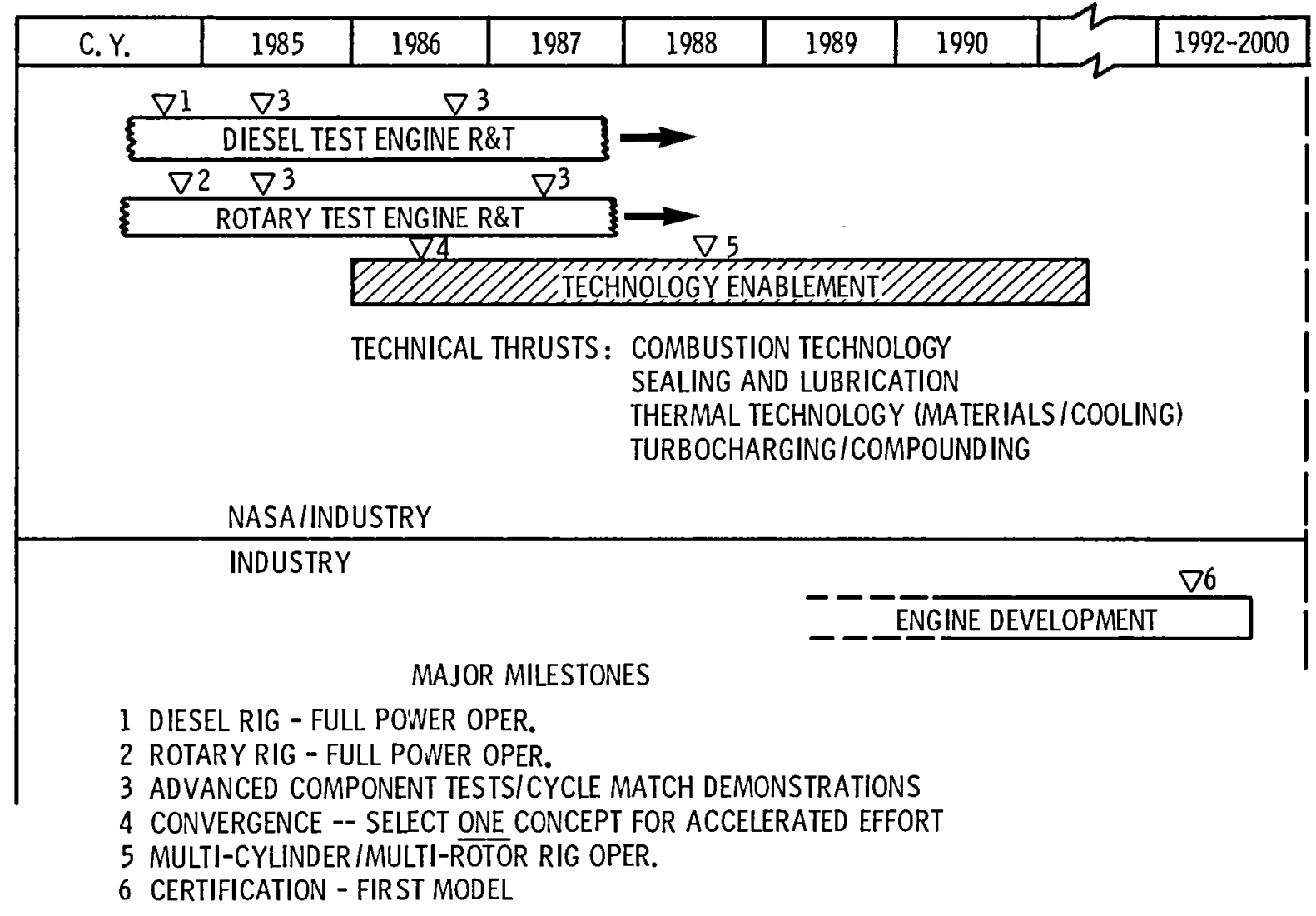

Figure 31. - Advanced I. C. engine research and technology - major schedule events. 


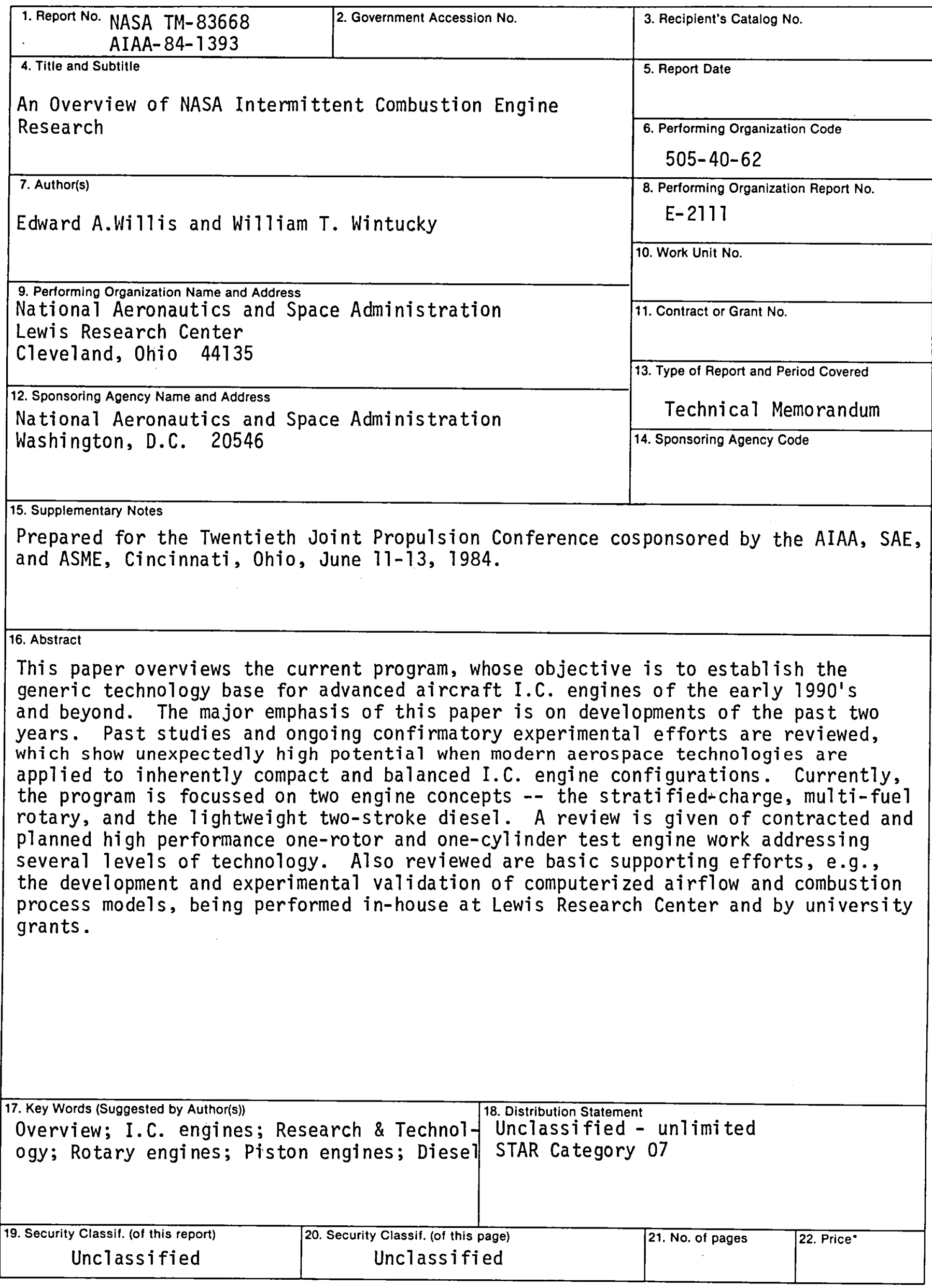

"For sale by the National Technical Information Service, Springfield, Virginia 22161 

National Aerorautics and Space Administration

Washington, D.C.

20546

Official Business

Penalty for Private Use, $\$ 300$
SPECIAL FOURTH CLASSMAIL BOOK

Postege and Fees Paid National Aeroneutics and Space Administration

NASA-451 